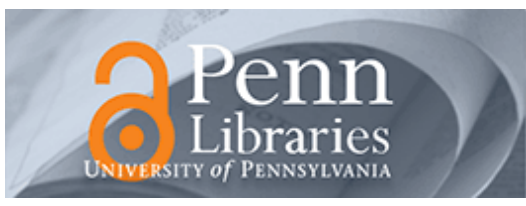

University of Pennsylvania ScholarlyCommons

Wharton Pension Research Council Working

Papers

Wharton Pension Research Council

$3-1-2013$

\title{
The Economic Importance of Financial Literacy: Theory and Evidence
}

Annamaria Lusardi

The George Washington University School of Business, alusardi@gwu.edu

Olivia S. Mitchell

The Wharton School, University of Pennsylvania, mitchelo@wharton.upenn.edu

Follow this and additional works at: https://repository.upenn.edu/prc_papers

Part of the Economics Commons

Lusardi, Annamaria and Mitchell, Olivia S., "The Economic Importance of Financial Literacy: Theory and Evidence" (2013). Wharton Pension Research Council Working Papers. 108.

https://repository.upenn.edu/prc_papers/108

This paper is posted at ScholarlyCommons. https://repository.upenn.edu/prc_papers/108

For more information, please contact repository@pobox.upenn.edu. 


\title{
The Economic Importance of Financial Literacy: Theory and Evidence
}

\begin{abstract}
In this paper, we undertake an assessment of the rapidly growing body of research on financial literacy. We start with an overview of theoretical research which costs financial knowledge as a form of investment in human capital. Endogenizing financial knowledge has important implications for welfare as well as policies intended to enhance levels of financial knowledge in the larger population. Next, we draw on recent surveys to establish how much (or how little) people know and identify the least financially savvy population subgroups. This is followed by an examination of the impact of financial literacy on economic decision-making in the United States and elsewhere. While the literature is still growing, conclusions may be drawn about the effects and consequences of financial illiteracy and what works to remedy these gaps. A final section offers thoughts on what remains to be learned if researchers are to better inform theoretical and empirical models as well as public policy.
\end{abstract}

\section{Disciplines}

Economics 


\title{
The Economic Importance of Financial Literacy: Theory and Evidence
}

\author{
Annamaria Lusardi and Olivia S. Mitchell
}

March 2013

\author{
PRC WP2013-02 \\ Pension Research Council Working Paper \\ Pension Research Council \\ The Wharton School, University of Pennsylvania \\ 3620 Locust Walk, 3000 SH-DH \\ Philadelphia, PA 19104-6302 \\ Tel: 215.898.7620 Fax: 215.573.3418 \\ Email:prc@wharton.upenn.edu \\ http://www.pensionresearchcouncil.org
}

The research reported herein was performed pursuant to a grant from the TIAA-CREF Institute; additional research support was provided by the Pension Research Council and Boettner Center at the Wharton School of the University of Pennsylvania. The authors thank Tabea Bucher-Koenen, Janet Currie, and Maarten van Rooij for suggestions, and Carlo de Bassa Scheresberg, Hugh Kim, Donna St. Louis, and Yong Yu for research assistance. Opinions and conclusions expressed herein are solely those of the authors and do not represent the opinions or policy of the funders or any other institutions with which the authors are affiliated. (C2013 Lusardi and Mitchell. All rights reserved.

All findings, interpretations, and conclusions of this paper represent the views of the authors and not those of the Wharton School or the Pension Research Council. (C2013 Pension Research Council of the Wharton School of the University of Pennsylvania. All rights reserved. 


\title{
The Economic Importance of Financial Literacy: Theory and Evidence
}

\begin{abstract}
$\underline{\text { Abstract }}$
In this paper, we undertake an assessment of the rapidly growing body of research on financial literacy. We start with an overview of theoretical research which costs financial knowledge as a form of investment in human capital. Endogenizing financial knowledge has important implications for welfare as well as policies intended to enhance levels of financial knowledge in the larger population. Next, we draw on recent surveys to establish how much (or how little) people know and identify the least financially savvy population subgroups. This is followed by an examination of the impact of financial literacy on economic decision-making in the United States and elsewhere. While the literature is still growing, conclusions may be drawn about the effects and consequences of financial illiteracy and what works to remedy these gaps. A final section offers thoughts on what remains to be learned if researchers are to better inform theoretical and empirical models as well as public policy.
\end{abstract}

\author{
Annamaria Lusardi \\ The George Washington University \\ School of Business \\ 2201 G Street, NW \\ Duquès Hall, Suite 450E \\ Washington, DC 20052 \\ alusardi@gwu.edu \\ Olivia S. Mitchell \\ The Wharton School \\ University of Pennsylvania \\ 3000 Steinberg Hall-Dietrich Hall \\ 3620 Locust Walk \\ Philadelphia, PA 19104 \\ mitchelo@wharton.upenn.edu
}




\title{
The Economic Importance of Financial Literacy: Theory and Evidence
}

\author{
Annamaria Lusardi and Olivia S. Mitchell
}

\section{Introduction}

Financial markets around the world have become increasingly accessible to the 'small investor,' as new products and financial services grow widespread. At the onset of the recent financial crisis, consumer credit and mortgage borrowing had burgeoned. People who had credit cards or subprime mortgages were in the historically unusual position of being able to decide how much they wanted to borrow. Alternative financial services, including payday loans, pawn shops, auto title loans, tax refund loans, and rent-to-own shops have also become widespread. ${ }^{1}$ At the same time, changes in the pension landscape increasingly thrust responsibility for saving, investing, and decumulating wealth onto workers and retirees. Forty years ago, older Americans relied mainly on Social Security and employer-sponsored defined benefit (DB) pension plans in retirement, with participants mainly deciding when to claim benefits. Today, by contrast, Baby Boomers mainly have defined contribution (DC) plans and Individual Retirement Accounts (IRAs) during their working years, which require them to decide how much to save and where to invest. $^{2}$ Moreover, during retirement, Boomers will increasingly need to take on responsibility for careful decumulation so as not to outlive their assets while meeting their needs.

Yet many of these widely available financial products - student loans, mortgages, credit cards, pension accounts, annuities - have proven to be complex and difficult for financially unsophisticated investors to master. So while financial and pension developments have their advantages, by permitting tailored financial contracts and more people to access credit, they also

\footnotetext{
${ }^{1}$ See Lusardi (2011) and FINRA Investor Education Foundation (2009).

${ }^{2}$ In the early 1980's, around 40 percent of U.S. private-sector pension contributions went to DC plans; two decades later, almost 90 percent of such contributions went to retirement accounts (mostly 401(k) plans; Poterba, Venti, and Wise 2008).
} 
impose on households a much greater responsibility to borrow, save, invest, and decumulate their assets sensibly.

One of our goals in this paper is to offer an assessment of how well-equipped today's households are to make these complex financial decisions. Specifically we focus on financial literacy, by which we mean peoples' ability to process economic information and make informed decisions about financial planning, wealth accumulation, pensions, and debt. In what follows, we outline recent theoretical research showing how financial knowledge can be cast as a type of investment in human capital. In this approach, those who build financial savvy can earn aboveaverage expected returns on their investments, yet there will still be some optimal level of financial ignorance. Endogenizing financial knowledge in this way has important implications for welfare, and offers insights into programs intended to enhance levels of financial knowledge in the larger population. Another goal is to assess the effects of financial literacy on behavior. We draw on surveys to establish how much (or how little) people know and which subgroups are the least financially literate. Most important, we evaluate the impact of financial literacy on economic decision-making in the United States and abroad, and what policies might help fill these gaps. The paper concludes with thoughts on what remains to be learned to better inform theoretical and empirical models, as well as public policy.

\section{A Theoretical Framework for Financial Literacy}

The conventional economic approach to saving and consumption decisions posits that a fully rational and well-informed individual will consume less than his income in times of high earnings, and he will save to support consumption when income falls (e.g. after retirement). In this context, building on Modigliani and Brumberg (1954) and Friedman (1957), the consumer is 
posited to arrange his optimal saving and decumulation patterns to smooth marginal utility over his lifetime. Many studies have shown how such a life cycle optimization process can be shaped by consumer preferences (e.g. risk aversion and discount rates), the economic environment (e.g. risky returns on investments and liquidity constraints), and social safety net benefits (e.g. the availability and generosity of welfare schemes and Social Security income), among other features. ${ }^{3}$

Theoretical models incorporating such key aspects of consumer behavior and the economic environment implicitly assume that people are able to formulate and execute saving and spend-down plans, all of which require expertise in dealing with financial markets, knowledge of purchasing power, and the capacity to undertake complex economic calculations. As we show below in more detail, this is far from true in the real world: very few people possess the extensive financial knowledge conducive to making and executing complex plans. Moreover, acquiring such knowledge is likely to come at a cost. In the past, when retirement pensions were implemented and managed by governments, individual workers tended to devote little attention to the plan details. Today, by contrast, saving, investment, and decumulation for retirement are occurring in an increasingly personalized pension environment. Accordingly, researchers and policymakers have begun to push for additional insights into the gaps between modeling and reality, so as to better evaluate where the theory can be enriched, and how policy efforts can be better targeted.

\footnotetext{
${ }^{3}$ For an older review of the saving literature see Browning and Lusardi (1996); recent surveys are provided by Skinner (2007) and Attanasio and Weber (2010). A very partial list of the literature discussing new theoretical advances includes Cagetti (2003); Chai, Horneff, Maurer and Mitchell (2012); DeNardi, French, and Jones (2011); French (2005, 2008); Gourinchas and Parker (2002); Hurst and Aguiar (2005, 2007); and Scholz, Seshadri, and Khitatrakun (2006).
} 
While there is a substantial theoretical and empirical body of work on the economics of education, ${ }^{4}$ far less attention has been devoted to the question of how people acquire and deploy financial literacy. In the last few years, however, a few authors have begun to explore the decision to acquire financial literacy and the links between financial knowledge, saving, and investment behavior including Delavande, Rohwedder, and Willis (2008), Jappelli and Padula (2011), Hsu (2011), and Lusardi, Michaud, and Mitchell (2013). ${ }^{5}$ The study by Delavande, Rohwedder, and Willis (2008) presents a simple two-period model of consumer saving and portfolio allocation across safe bonds and risky stocks, allowing for the acquisition of human capital in the form of financial knowledge (à la Ben-Porath, 1967, and Becker, 1975). This work posits that individuals will optimally elect to invest in financial knowledge so as to gain access to higher-return assets: this training helps them identify better-performing assets and/or hire financial advisers who can reduce investment expenses. Hsu (2011) uses a similar approach in an intra-household setting where husbands specialize in the acquisition of financial knowledge, but women are predicted to increase their acquisition of financial knowledge when it becomes relevant, such as prior to the death of their spouse. Jappelli and Padula (2011) also consider a two-period model but additionally sketch a multi-period life cycle model with financial literacy endogenously determined. They predict that financial literacy and wealth will be strongly correlated over the life cycle, with both rising until retirement and falling thereafter. They also suggest that, in countries with generous Social Security benefits, there will be fewer incentives to save and accumulate wealth and, in turn, less reason to invest in financial literacy.

\footnotetext{
${ }^{4}$ Glewwe (2002) and Hanusheck and Woessman (2008) review the economic impacts of schooling and cognitive development.

${ }^{5}$ Another related study is by Benitez-Silva, Demiralp, and Liu (2009) who use a dynamic life cycle model of optimal Social Security benefit claiming against which they compare outcomes to those generated under a suboptimal information structure where people simply copy those around them when deciding when to claim benefits. The authors do not, however, allow for endogenous acquisition of information.
} 
Each of these studies represents a useful theoretical advance, yet none incorporates borrowing constraints, mortality risk, demographic factors, stock market returns, and earnings and health shocks, all now standard in theoretical models of saving. These shortcomings are rectified in the multi-period model of Lusardi, Michaud, and Mitchell (2011, 2013), who calibrate and simulate a dynamic life cycle approach where individuals not only select capital market investments but also undertake investment in financial knowledge. This extension is important in that it permits researchers to examine model implications for wealth inequality and welfare. That paper posits two distinct technologies for investing: the first is a simple one which pays a fixed low rate of return each period $(\bar{R}=1+\bar{r})$, similar to a bank account, while the second is a more sophisticated technology providing the consumer access to a higher stochastic expected return, $\tilde{R}\left(f_{t}\right)$, which depends on his accumulated level of financial knowledge. Each period, the stock of knowledge is related to what the individual had in the previous period minus a depreciation factor: thus $f_{t+1}=\delta f_{t}+i_{t}$, where $\delta$ represents knowledge depreciation (due to obsolescence or decay) and gross investment is $i_{t}$. The stochastic return from the sophisticated technology follows the process $\tilde{R}\left(f_{t+1}\right)=\bar{R}+r\left(f_{t+1}\right)+\sigma_{\varepsilon} \varepsilon_{t+1}$ (where $\varepsilon_{\mathrm{t}}$ is a $\mathrm{N}(0,1)$ iid shock and $\sigma_{\varepsilon}$ refers to the standard deviation of returns on the sophisticated technology). To access this higher expected return, the consumer must pay both a direct cost (c), and a time and money cost ( $\pi)$ to build up his knowledge. ${ }^{6}$

\footnotetext{
${ }^{6}$ This cost function is assumed to be convex but the authors also experiment with alternative formulations, which does not alter results materially. Kézdi and Willis (2011) also model heterogeneity in beliefs about the stock market, where people could learn about the statistical process governing stock market returns, which reduced transactions costs for investments. Here, however, the investment cost is cast as a simplified flat fixed fee per person, whereas Lusardi, Michaud, and Mitchell (2013) evaluate more complex functions of time and money costs for investment in knowledge.
} 
Prior to retirement, the individual earns risky labor income $(y)$ from which he can consume (c) or invest so as to raise his return (R) on saving (s) by investing in the sophisticated technology. After retirement, he receives Social Security benefits which are a percentage of preretirement income. ${ }^{7}$ Additional sources of uncertainty include stock returns, medical costs, and longevity. Each period, therefore, the consumer's decision variables are how much to invest in the capital market, consume $(c)$, and whether to invest in financial knowledge.

Assuming a discount rate of $\beta$ and $\eta_{o}, \eta_{y}$, and $\varepsilon$ which refer, respectively, to shocks in medical expenditures, labor earnings, and rate of return, the problem takes the form of a series of Bellman equations with the following value function $V_{d}\left(s_{t}\right)$ at each age as long as the individual is alive $\left(p_{e, t}>0\right)$ :

$$
V_{d}\left(s_{t}\right)=\max _{c_{t}, i_{t}, \kappa_{t}} n_{e, t} u\left(c_{t} / n_{e, t}\right)+\beta p_{e, t} \int_{\varepsilon} \int_{\eta_{y}} \int_{\eta_{o}} V\left(s_{t+1}\right) d F_{e}\left(\eta_{o}\right) d F_{e}\left(\eta_{y}\right) d F(\varepsilon)
$$

The utility function is assumed to be strictly concave in consumption and scaled using the function $u\left(c_{t} / n_{t}\right)$ where $n_{t}$ is an equivalence scale capturing family size which changes predictably over the life cycle; and by education, subscripted by $e$. End-of-period assets $\left(a_{t+1}\right)$ are equal to labor earnings plus the returns on the previous period's saving plus transfer income (tr), minus consumption and costs of investment in knowledge (as long as investments are positive; i.e., $\kappa>0)$. Accordingly, $a_{t+1}=\tilde{R}_{\kappa}\left(f_{t+1}\right)\left(a_{t}+y_{e, t}+t r_{t}-c_{t}-\pi\left(i_{t}\right)-c_{d} I\left(\kappa_{t}>0\right)\right)$. $^{8}$

After calibrating the model using plausible parameter values, the authors then solve the value functions for consumers with low/medium/high educational levels by backward recursion

\footnotetext{
${ }^{7}$ There is also a minimum consumption floor; see Lusardi, Michaud, and Mitchell (2011, 2013).

${ }^{8}$ Assets must be non-negative each period and there is a nonzero mortality probability as well as a finite length of life.
} 
after discretizing the continuous state variables. ${ }^{9}$ Given paths of optimal consumption, knowledge investment, and participation in the stock market, they then simulate 5,000 life cycles allowing for return, income, and medical expense shocks. ${ }^{10}$

Several key predictions emerge from this study. First, endogenously-determined optimal paths for financial knowledge will be hump-shaped over the life cycle. Second, consumers will invest in financial knowledge to the point where their marginal time and money costs of doing so are equated to their marginal benefits; of course, this optimum will depend on the cost function for financial knowledge acquisition. Third, knowledge profiles will differ across educational groups because of peoples' different life cycle income profiles.

Importantly, this model predicts that inequality in wealth and financial knowledge will arise endogenously, without needing to assume cross-sectional differences in preferences or making other major changes to the theoretical setup. ${ }^{11}$ Moreover, differences in wealth across education groups also arise endogenously. In other words, this framework suggests that some population sub-groups will have persistently low financial literacy, particularly those anticipating substantial safety net income in old age. Finally, this approach implies that financial education programs should not be expected to produce large behavioral changes for the least educated. This is because it may not be worthwhile for the least educated to incur knowledge investment costs, given that their consumption needs are better insured by transfer programs. ${ }^{12}$ The finding is consistent with Jappelli and Padula's (2011) suggestion that less financially informed individuals will be found in countries with more generous Social Security benefits (see also Jappelli 2010).

\footnotetext{
${ }^{9}$ Additional detail on calibration and solution methods appears in Lusardi, Mitchell, and Michaud (2011, 2013).

${ }^{10}$ Initial conditions for education, earnings, and assets were derived from PSID respondents age 25-30.

${ }^{11}$ This may account for otherwise "unexplained" wealth inequality, as discussed in Venti and Wise (2001).

12 These predictions directly contradict at least one lawyer's surmise that "[i]n an idealized first-best world, where all people are far above average, education would train every consumer to be financially literate and would motivate every consumer to use that literacy to make good choices" (Willis 2008).
} 
Despite the fact that some people will rationally choose to invest little or nothing in financial knowledge, it is nonetheless interesting to note that it still can be socially optimal to raise financial knowledge for everyone early in life, such as by mandating financial education in high school. This is because even if the least educated never invest again and let their knowledge endowment depreciate, they still will earn higher returns on their saving, which generates a substantial welfare boost. For instance, providing pre-labor market financial knowledge to the least educated group improves their wellbeing by an amount equivalent to 82 percent of their initial wealth (Lusardi, Michaud, and Mitchell 2011). The wealth equivalent value for college graduates is also estimated to be substantial, at 56 percent. While these estimates are specific to the parameters of that particular model, it seems clear that consumers will value accumulating financial knowledge early in life, even if they make no new investments thereafter.

In sum, the theoretical literature on financial literacy has made strides in recent years by endogenizing the process of financial knowledge acquisition, generating predictions that can be tested empirically, and offering a coherent way to evaluate policy options. Moreover, these models offer insights into how policymakers might enhance welfare by enhancing young workers' endowment of financial knowledge. In the next section, we turn to a review of empirical evidence on financial literacy and how to measure it in practice.

\section{Measuring Financial Literacy}

Several fundamental concepts lie at the root of saving and investment decisions as modeled in the life cycle setting described in the previous section. Three such concepts are: (i) numeracy and capacity to do calculations related to interest rates, such as compound interest; (ii) understanding of inflation; and (iii) understanding of risk diversification. Translating these 
into easily-measured financial literacy metrics is difficult, but Lusardi and Mitchell (2008, $2011 \mathrm{~b}, \mathrm{c}$ ) have designed a standard set of questions around these ideas and implemented them in numerous surveys in the United States and abroad.

Four principles drove the design of these questions, namely Simplicity: The questions should measure knowledge of the building blocks fundamental to decision-making in an intertemporal setting; Relevance: The questions should relate to concepts pertinent to peoples' day-to-day financial decisions over the life cycle; moreover, they must capture general rather than context-specific ideas; Brevity: The number of questions must be kept short to secure widespread adoption; and Capacity to differentiate: Questions must differentiate between financial knowledge levels, so as to permit comparisons across people. These criteria are met by the three financial literacy questions designed by Lusardi and Mitchell (2008, 2011b), whose wording is reported below:

- Suppose you had $\$ 100$ in a savings account and the interest rate was $2 \%$ per year. After 5 years, how much do you think you would have in the account if you left the money to grow: [more than $\$ 102$, exactly $\$ 102$, less than $\$ 102$ ? Do not know, refuse to answer.]

- Imagine that the interest rate on your savings account was $1 \%$ per year and inflation was $2 \%$ per year. After 1 year, would you be able to buy: [more than, exactly the same as, or less than today with the money in this account? Do not know; refuse to answer.]

- Do you think that the following statement is true or false? 'Buying a single company stock usually provides a safer return than a stock mutual fund.' [Do not know; refuse to answer.]

The first question measures numeracy or the capacity to do a simple calculation related to compounding of interest rates. The second question measures understanding of inflation, again in the context of a simple financial decision. The third question is a joint test of knowledge about 'stocks' and 'stock mutual funds' and of risk diversification, since the answer to this question 
depends on knowing what a stock is and that a mutual fund is composed of many stocks. As is clear from the theoretical models described earlier, many decisions about retirement savings must deal with financial markets. Accordingly, it is important to understand knowledge of the stock market as well as differentiate between levels of financial knowledge.

Naturally any measure of financial literacy will suffer from limitations, and it is clear that financial literacy measures serve simply as proxies for what intertemporal models of financial decision-making would posit that individuals will need to know, in order to properly optimize. ${ }^{13}$ Moreover, there is always the possibility of measurement error as well as the possibility that answers might not measure 'true' financial knowledge. These concerns have implications for empirical work on financial literacy, as will be discussed below.

\section{Financial Literacy of Adults}

The three questions above were first piloted in a special financial literacy module of the 2004 Health and Retirement Study (HRS) ${ }^{14}$ on U.S. respondents age 50 and older. Results indicated that the older U.S. population was quite financially illiterate: as described in Table 1, only about half the HRS respondents age 50+ could answer the simple 2 percent calculation and knew about inflation; only a third could answer all three questions correctly (Lusardi and Mitchell 2011b). This is despite the fact that people in this age group would have made many financial decisions and engaged in numerous financial transactions over their lifetimes. Moreover, these respondents had experienced two or three periods of very high inflation (depending on their ages) and had witnessed numerous economic and stock market shocks (including the demise of Enron), which should have provided them with information about investment risk.

\footnotetext{
${ }^{13}$ See Houston (2010) for a detailed discussion of financial literacy measures and a review of what has been proposed so far.

${ }^{14}$ For information about the HRS, see http://hrsonline.isr.umich.edu/
} 


\section{Table 1 here}

These three questions were also added to several other U.S. surveys thereafter, including the 2007-2008 National Longitudinal Survey of Youth for young respondents (ages 23-28) (Lusardi, Mitchell, and Curto 2010); the RAND American Life Panel (ALP) covering all ages (Lusardi and Mitchell 2009); and the 2009 Financial Capability Study (Lusardi and Mitchell 2011d). ${ }^{15}$ Findings from these surveys underscore and extend the HRS results: for all groups, the level of financial literacy in the U.S. is low.

To supplement findings from these three questions, additional and more sophisticated concepts have also been added to the repertoire of financial literacy questions. The FINRA Financial Capability Survey includes a longer set of queries (Lusardi 2011), including two items measuring sophisticated concepts such as understanding of mortgages/mortgage payments and asset pricing. Results from this longer set of questions reveal additional gaps in knowledge: for example, only a small percentage of Americans (21\%) knows about the inverse relationship between bond prices and interest rates. Additional studies exploring more complex but similar financial knowledge measures include Kimball and Shumway (2006), Lusardi and Mitchell (2009), Yoong (2011), Hung, Parker, and Yoong (2009), Lusardi, Mitchell, and Curto (2012), and the review in Houston (2010). ${ }^{16}$ Many of these measures include questions on the difference between bonds and stocks, asset prices, and differences in returns and risks across financial instruments. A pass/fail series of 28 questions covering knowledge of credit, saving patterns, mortgages, and general financial management by Hilgert, Hogarth, and Beverly (2003) shows

\footnotetext{
${ }^{15}$ These questions were also added to the second wave of the FINRA Financial Capability Study in 2012.

${ }^{16}$ Surveys in other countries have also examined complex financial literacy concepts, see for example the Dutch Central Bank Household Survey (Alessie, van Rooij, and Lusardi 2011).
} 
that most people earn a failing score on these questions as well. ${ }^{17}$ Additional surveys have examined financial knowledge in the context of debt, for example knowledge of interest compounding, when interest rates can be rather high and therefore very salient. Lusardi and Tufano (2009a, b) show that 'debt literacy' is low as well: only one-third of respondents knew how long it would take for debt to double if one were to borrow at a 20 percent interest rate. This lack of knowledge confirms conclusions from Moore's (2003) survey of Washington state residents where she finds that people frequently fail to understand interest compounding, along with the terms and conditions of consumer loans and mortgages. Moreover, knowledge of risk and risk diversification remains low even when the questions are formulated in many different ways (c.f., Kimball and Shumway 2006; Yoong 2011; and Lusardi, Schneider and Tufano 2011). In other words, all of these surveys confirm that most U.S. respondents are not financially literate.

\section{Financial Literacy among the Young}

As described in the earlier discussion of theoretical models, it would be useful to know the level of financial knowledge at the start of the working life (Jappelli 2010). Several authors have measured high school students' financial literacy using data from the Jump\$tart Coalition for Personal Financial Literacy and the Council for Financial Education (CEE). Because these studies include a long list of questions, they provide a quite nuanced evaluation of what students know. Here too, as we have seen for their adult counterparts, most high school students in the U.S. receive a failing grade in financial literacy (Mandell 2008; Markow and Bagnaschi 2005). Similar findings are reported for financial literacy among college students (Chen and Volpe 1998; and Shim, Barber, Card, Xiao, and Serido 2010).

\footnotetext{
${ }^{17}$ Similar findings are reported for smaller samples or specific population subgroups (c.f. Agnew and Szykman 2011; Utkus and Young 2011).
} 


\section{International Evidence}

The goal of evaluating student financial knowledge around the world has recently been taken up by the OECD's Programme for International Student Assessment (PISA), which in 2012 added a module on financial literacy. Accordingly, students across several nations will soon be able to be compared in terms of their financial knowledge in addition to their knowledge of math, science, and reading. In so doing, PISA has taken the position that financial literacy is now recognized as an essential skill to be able to operate in today's economy. ${ }^{18}$

Rather more is known about adults' financial literacy levels around the world, since the three basic questions measuring financial knowledge have now been implemented in national surveys in Germany, the Netherlands, Italy, Sweden, Russia, Japan, and New Zealand (Lusardi and Mitchell 2011c). Additionally they have been fielded in Australia (Agnew, Bateman, and Thorp 2012; Bateman, Ebling, Geweke, Louviere, Satchell, and Thorp 2013), France (Arrondel, Debbich, and Savignac 2012); Mexico and Chile (Hastings and Tejeda-Ashton 2008; Hastings and Mitchell 2011; Behrman, Bravo, Mitchell and Soo 2012), India and Indonesia (Cole, Sampson, and Zia 2011); and Switzerland (Brown and Graf 2012). They have also been used to measure financial literacy among Sri Lankan entrepreneurs (de Mel, McKenzie, and Woodruff 2008) and a sample of U.S.-based migrants from El Salvador (Ashraf, Aycinena, Martinez, and Yang 2011). The Organization for Economic Co-operation and Development (OECD 2005) confirmed extensive financial illiteracy in Europe, Australia, and Japan in an earlier survey. More recently, Atkinson and Messy (2012) also find substantial financial illiteracy in 14 countries at different stages of development in four continents, using a 'harmonized' set of

\footnotetext{
${ }^{18}$ For more information on the Financial Literacy Framework in PISA, see: http://www.oecd.org/pisa/pisaproducts/46962580.pdf
} 
financial literacy questions. ${ }^{19}$ In other words, low levels of financial literacy are evident around the world.

Rather than attempting to detail all existing financial literacy studies, we highlight and summarize some key findings (see Figure 1). First, very few people across countries can answer three basic financial literacy questions correctly. In the U.S., only 30 percent can do so, with similar low percentages in countries having well-developed financial markets (Germany, the Netherlands, Japan, and New Zealand), as well as in nations where financial markets are changing rapidly (Russia). In other words, low levels of financial literacy found in the U.S. are also prevalent elsewhere, rather than being specific to any given country or stage of economic development. Moreover, many respondents say they 'do not know' the answers to the questions (Lusardi and Mitchell 2011c).

Figure 1 here

Second, knowledge of inflation is related to national historical experience. For example, Italians and Germans are more likely to know the answer to the inflation question, whereas in Japan, which has experienced deflation, many fewer people do so. Third, of the questions examined, risk diversification is the concept people have the most difficulty grasping, Indeed, virtually everywhere a high share of people respond that they 'do not know' the answer to the risk diversification question; for example, in the U.S., 34 percent of respondents state they do not know the answer to the risk diversification question, while in Germany 32 percent and in the Netherlands 33 percent do so. The most risk-savvy population is to be found in Sweden which

\footnotetext{
${ }^{19}$ Their survey uses eight financial literacy questions and focuses on fundamental concepts including the three main concepts discussed earlier.
} 
has privatized a component of its national Social Security system: here only 18 percent state that they do not know the answer to the risk diversification question. ${ }^{20}$

Third, research also notes that peoples' responses to survey questions cannot always be taken at face value, something well-known to psychometricians and economic statisticians. One reason, as noted above, is that financial literacy may be measured with error, depending on the way questions are worded. To test this possibility, Lusardi and Mitchell (2009) and van Rooij, Lusardi, and Alessie (2011) randomly ask two groups of respondents the same risk question but in different order. Thus half the group receives format (a) and the other half format (b), as follows:

(a) Buying a company stock usually provides a safer return than a stock mutual fund. True or false?

OR

(b) Buying a stock mutual fund usually provides a safer return than a company stock. True or false?

Results show that people's responses are, indeed, sensitive to how the question is worded, in both the U.S. American Life Panel (Lusardi and Mitchell 2009) and the Dutch Central Bank Household Survey (DHS; van Rooij, Lusardi, and Alessie 2011). For example, fewer DHS respondents answer correctly when the wording is 'buying a stock mutual fund usually provides a safer return than a company stock'; conversely, the fraction of correct responses doubles given the alternative wording: 'buying a company stock usually provides a safer return than a stock mutual fund.' This is not simply due to people using a crude rule of thumb (such as always picking the first as the correct answer), since that would generate a lower rather than a higher percentage of correct answers for version (a). Instead, it appears that some respondents do not understand the question, perhaps because they are unfamiliar with stocks, bonds, and mutual

\footnotetext{
${ }^{20}$ Researchers have also examined answers to questions on mathematical numeracy in the England Longitudinal Survey of Ageing (ELSA; Banks and Oldfield 2007), and in the Survey of Health, Ageing, and Retirement in Europe (SHARE; Christelis, Jappelli, and Padula 2010).
} 
funds. What this means is that some answers judged to be 'correct' may instead be attributable to guessing. In other words, analysis of the financial literacy questions should take into account the possibility that these measures may be noisy proxies of true financial knowledge levels. ${ }^{21}$

Another interesting feature of the data on financial literacy is that there is often a substantial mismatch between peoples' self-assessed knowledge versus their actual knowledge as measured by correct answers to the financial literacy questions posed. As one example, several surveys include questions asking people to indicate their self-assessed knowledge, as follows:

- On a scale from 1 to 7 , where 1 means very low and 7 means very high, how would you assess your overall financial knowledge?'

Even though actual financial literacy levels are low, respondents are in general rather confident of their financial knowledge. Indeed, overall, they tend to overestimate their levels of knowledge. For instance in the 2009 U.S. Financial Capability Study, 70 percent of respondents gave themselves score of 4 or higher (out of 7), but only 30 percent of the same people could correctly answer the factual questions (Lusardi, 2011). Similar findings are reported in other surveys (Lusardi and Tufano 2009a) and they also obtain for Germany and the Netherlands (van Rooij, Lusardi, and Alessie 2011; Bucher-Koenen and Lusardi 2011). In other words, though actual financial literacy is low, most people are unaware of their own shortcomings.

\section{Disaggregating Financial Literacy}

\footnotetext{
${ }^{21}$ In the 2008 HRS the financial literacy questions were again modified to assess the sensitivity of peoples' answers to the way in which the questions were worded. Results confirm the sensitivity of question wording, especially for the more sophisticated financial concepts (Lusardi, Mitchell, and Curto 2012). Behrman, Bravo, Mitchell and Soo (2012) develop a financial literacy index employing a two-step weighting approach, whereby the first step weights each question by difficulty and the second step applies principal components analysis to take into account correlations across questions. Resulting scores indicate how financially literate each individual is, in relation to the average and to specific questions asked. The results indicate that the basic financial literacy questions designed by Lusardi and Mitchell (2011b) receive the greatest weights.
} 
Next we turn to a disaggregated assessment of which particular subgroups may be most likely to lack financial literacy, to draw out lessons about what might facilitate financial knowledge acquisition. In what follows, we review evidence by income and employment status, age and sex, race/ethnicity, and other factors of interest to researchers.

Patterns by Age

The theoretical framework outlined above predicts a hump-shaped profile of financial literacy over the life cycle, and survey data confirm that financial literacy is, in fact, lowest among the young and the old. Earlier we made mention of the widespread lack of financial and economic knowledge among high school students (Markow and Bagnaschi 2005; Mandell 1997, 2008). College and young adults also display low knowledge, confirming that many start their working career with low levels of financial literacy (Chen and Volpe 1998; Lusardi, Mitchell, and Curto 2010).

At the other end of the work life, financial literacy also declines with age, as found in the 2004 HRS module on financial literacy on people age 50+ and in many other countries (Lusardi and Mitchell 2011b, c). Of course with cross-sectional data, one cannot cleanly disentangle age from cohort effects, and further analysis will be required to parse out these factors. Quite remarkable, nonetheless, is the fact that older people are quite self-assured regarding their own financial literacy, despite scoring worse on the basic financial literacy questions (Lusardi and Mitchell 2011b; Lusardi and Tufano 2009a). Similarly, Finke, Howe, and Houston (2011) develop a multidimensional measure of financial literacy for the old and confirm that, though actual financial literacy falls with age, peoples' confidence in their own financial decisionmaking abilities actually increases with age. The mismatch between actual and perceived 
knowledge might explain why financial scams are often perpetrated against the elderly (Deevy, Lucich, and Beals 2012).

Patterns by Sex

Several researchers exploring financial literacy patterns have also uncovered large sex differences in financial literacy (Lusardi and Mitchell 2008, 2011d; Hsu 2011; Fonseca, Mullen, Zamarro, and Zissimopolous 2012; Hung, Yoong, and Brown (2012); Bucher-Koenen, Lusardi, Alessie, and van Rooij 2012). Interestingly, financial literacy differences by sex are found in over a dozen countries as different as the United States, Sweden, Italy, Russia, and New Zealand, as well as elsewhere (Atkinson and Messy 2012). Not only are older men generally more financially knowledgeable than older women, but similar patterns show up among younger respondents as well (Lusardi, Mitchell, and Curto 2010; Lusardi and Mitchell 2009; Lusardi and Tufano 2009a, b); Moreover, the gaps persist irrespective of whether one uses the basic literacy questions or the more sophisticated ones (Lusardi, Mitchell, and Curto 2012; Hung, Parker, and Yoong 2009).

A twist on the differences by sex, however, is that while women are less likely to answer financial literacy questions correctly than men, they are also far more likely to say they 'do not know' an answer to a question, a result that is strikingly consistent across countries. For example, in the United States, about one quarter (26 percent) of men answered the risk diversification question with 'I do not know,' but almost half (47 percent) of the women chose 'I do not know' as an answer. In the Netherlands, the percentages of 'do not know' to the risk diversification question are 26 percent for men and 42 percent for women; in Germany, 26 percent for men and 38 percent for women; the overall percentages are lower in Sweden but still higher for women (15 percent for men, 22 percent for women); and in Japan, 49 percent of men 
and 63 percent of women say 'I do not know.' And women are far more likely to rate themselves as having low financial knowledge, consistent with their high prevalence of 'do not know' responses. This awareness of their own lack of knowledge may make women ideal targets for financial education programs.

Because these sex differences in financial literacy are so persistent and widespread across surveys and countries, several researchers have sought to explain them. Consistent with the theoretical framework described earlier, Hsu (2011) proposes that some sex differences may be rational, with specialization of labor within the household leading married women to build up financial knowledge only late in life (close to widowhood). Nonetheless, this model does not explain why financial literacy is also lower among single women in charge of their own finances. Studies of financial literacy in high school and college also reveal sex differences in financial literacy early in life (Chen and Volpe 2002; Mandell 2008). Other researchers seeking to evaluate the reasons for observed sex differences conclude that traditional explanations cannot fully account for the observed male/female knowledge gap (Fonseca, Mullen, Zamarro, and Zissimopolous 2012; Bucher-Koenen, Lusardi, Alessie, and van Rooij 2012). Fonseca, Mullen, Zamarro, and Zissimopoulos (2012) suggest that women may acquire or 'produce' financial literacy differently from men, and Bucher-Koenen, Lusardi, Alessie, and van Rooij (2012) point to a potentially important role for self-confidence which differs by sex.

To shed more light on women's financial literacy, Mahdavi (2012) examines alumnae from a highly selective U.S. women's liberal arts college. Even in this talented and welleducated group, women's financial literacy was found to be very low. In other words, even very well educated women are not particularly financially literate, which could imply that women may acquire financial literacy differently from men. Nevertheless this issue is far from closed, 
and additional research is warranted to more fully explain the observed sex differences in financial literacy.

Patterns by Education and Ability

Researchers have also found substantial differences in financial knowledge by education: specifically, those without a college education are much less likely to grasp advanced financial concepts such as risk diversification (Lusardi and Mitchell 2007a, 2011b); moreover, numeracy is especially lacking among those with low educational attainment (Christelis, Jappelli, and Padula 2010). How to interpret the finding of a positive link between education and financial savvy has been subject to some debate in the economics literature. One possibility is that the positive correlation could be driven by cognitive ability (c.f. McArdle, Smith, and Willis 2009). In turn, this implies that one must control on an ability measure when evaluating the potential impact of financial literacy. Fortunately, the National Longitudinal Survey of Youth (NLSY) includes both measures of financial literacy and of cognitive ability (i.e., the Armed Services Vocational Aptitude Battery). Lusardi, Mitchell, and Curto (2010) report a positive correlation between financial literacy and cognitive ability among young NLSY respondents, but they also show that cognitive factors do not fully account for the variance in financial literacy. In other words, substantial heterogeneity in financial literacy remains even after controlling on cognitive factors.

Patterns by Income and Work Status

Financial literacy varies strongly with income (Lusardi and Tufano 2009a) as well as by employment type. Around the world, financial literacy is usually higher for employees than for the non-employed (Lusardi and Mitchell 2011c). Additionally, financial literacy is usually as 
high, or even higher, among the self-employed than the non-employed. This may be the result of learning on the job and in the workplace.

\section{Other Patterns}

Many financial literacy studies report marked differences by race and ethnicity, with African Americans and Hispanics displaying the lowest level of financial knowledge in the U.S. context (Lusardi and Mitchell 2007a, b, 2011d). These findings hold true across age groups and across many different measures of financial literacy (Lusardi and Mitchell 2009). It is also the case that people from rural areas score worse on financial literacy studies (Klapper and Panos 2011), perhaps reflecting the fact that city-dwellers differ from those residing in rural areas. If financial literacy is more easily acquired via interactions with others (assuming little formal instruction in schools), living in areas of high population density might offer an advantage. This might also help account for the sex differences mentioned above, since in many cultures, men are more likely than women to interact daily with financially knowledgeable individuals. Relatedly, there are also important geographic differences in financial literacy: for example, Fornero and Monticone (2011) report large differences in financial literacy across regions in Italy, and Bumcrot, Lin, and Lusardi (2011) note differences across U.S. states, suggesting that local policies may matter for financial literacy.

The literature also points to differences in financial literacy by family background. For instance, using the NLSY, Lusardi, Mitchell, and Curto (2010) link financial literacy of 23-28year-olds to characteristics of the households in which they grew up, controlling for a set of demographic and economic characteristics. Respondents' financial literacy proves to be strongly and significantly correlated with parental education (in particular, that of their mothers), and whether their parents held stocks or retirement accounts when the respondents were teenagers. 
Mahdavi (2012) also finds a connection between financial literacy and parental background; in this case, fathers' education is positively associated with their female children's financial literacy. ${ }^{22}$ In other words, financial literacy may well get its start in the family, perhaps when children observe their parents' saving and investing habits, or more directly by receiving financial education from parents (Chiteji and Stafford 1999; Li 2009; Shim, Xiao, Barber, and Lyons 2009).

To summarize, financial illiteracy is not only widespread but also particularly notable among specific population sub-groups. Accordingly, this heterogeneity in financial literacy suggests that different mechanisms may be appropriate for tracking the causes and possible consequences of the shortfalls. In the U.S., those facing most challenges are the young and the old, women, African-Americans, Hispanics, the least educated, and those living in rural areas. To date, these differences have not been fully accounted for, though the theoretical framework outlined above provides some guidelines for disentangling some of these.

\section{How Does Financial Literacy Matter?}

We turn next to a discussion of whether and how financial literacy matters for economic decision-making. ${ }^{23}$ Inasmuch as new financial products are always arriving to market, and individuals are increasingly being asked to take on additional responsibility for their own financial well-being, there remains much to learn about these patterns. And, as we have argued, if financial literacy itself is a choice variable, it is important to disentangle cause from effect. For instance, those with high net worth who invest in financial markets may also be more likely to care about improving their financial knowledge as they have more at stake. In what follows,

${ }^{22}$ Other studies discussing financial socialization of the young include Hira, Sabri, and Loibl (2013) and the references cited therein.

${ }^{23}$ For an earlier analysis of the importance of financial literacy, see Hira (2010) and the work cited therein. 
we discuss research linking financial literacy with economic outcomes, taking into account the endogeneity issues which are paramount.

Financial Literacy and Consumer Behavior

The early economics literature in this area began by documenting important links between financial literacy and several economic behaviors. For example Bernheim $(1995,1998)$ was among the first to emphasize that most U.S. households lack basic financial knowledge, leading them to use crude rules of thumb when engaging in saving behavior. More recently, using Swedish data, Calvet, Campbell, and Sodini (2007, 2009) evaluate investors' actions they classify as 'mistakes,' overcoming in this way the problem of causality between financial literacy and behavior. While these studies includes no direct financial literacy measure, the authors do find that poorer, less educated, and immigrant households (characteristics associated with low financial literacy) are more likely to make financial mistakes. Agarwal, Driscoll, Gabaix, and Laibson (2009) also focus on financial 'mistakes', as will be discussed in more detail below, and show that these are most prevalent among the young and the old. Several studies mentioned earlier have shown these are the groups with the least financial knowledge.

Moreover, the U.S. federal government has begun to express substantial concern about another and more extreme case of mistakes, where people fall prey to financial scams. As many have noted, scams are often perpetrated against the elderly since they are among those with the least financial savvy. ${ }^{24}$ For example, a survey of older financial decision makers (age $60+$ ) showed that over half reported having made a bad investment, and one in five of those respondents felt they were misled or defrauded but often fail to report the situation (FINRA

\footnotetext{
${ }^{24}$ In 2011 Americans submitted over 1.5 million complaints about financial and other fraud, up 62 percent in just three years; these counts are also likely understatements (FTC 2012). Financial losses per capita due to fraud have also increased over time: the median loss per victim rose from \$218 in 2002 to $\$ 537$ in 2011. Similarly the SEC (2012) warns about scams and fraud and other potential consequences of very low financial literacy, particularly among the most vulnerable groups.
} 
2006). As Baby Boomers age, this problem is expected to grow (Blanton 2012): this cohort is a potentially lucrative target inasmuch as it is enormous, including some 75 million people; it is relatively well-off and has access to its pension wealth; and it is not financially literate yet thinks itself quite knowledgeable.

Several researchers have explored the link between financial literacy and economic behavior directly, though often without accounting for the endogeneity issue noted above. For instance, Hilgert, Hogarth, and Beverly (2003) uncover strong correlation between financial literacy and day-to-day financial management skills. Moreover, there is evidence that the more numerate and financially literate are also more likely to participate in financial markets and invest in stocks (Kimball and Shumway 2006; Christelis, Jappelli, and Padula 2010; van Rooij, Lusardi, and Alessie 2011; Yoong 2011; Almenberg and Dreber 2011; Arrondel, Debbich, and Savignac 2012). It has also been shown that those who are more financially literate are also more likely to undertake retirement planning, and those who plan also accumulate more wealth (Lusardi and Mitchell 2007a, b, 2011a, b). This last finding has been replicated in many other datasets and for additional sub-groups of the population in the U.S. (Lusardi and Mitchell 2008, 2009, 2011d), as well as internationally (Lusardi and Mitchell 2011c). It is also robust to the measure of financial literacy used (basic versus sophisticated financial knowledge; Lusardi and Mitchell 2009, 2011d), how planning is measured (Lusardi and Mitchell 2007a, 2009, 2011b; Alessie, van Rooij, and Lusardi 2011), and which controls are included (van Rooij, Lusardi, and Alessie 2011).

Of all the specific components of a financial literacy measure, what matters most is advanced financial knowledge (for example, risk diversification) and the capacity to do calculations (Lusardi and Mitchell 2011d; Alessie, van Rooij, and Lusardi 2011; Fornero and 
Monticone 2011; Klapper and Panos 2011; Sekita 2011). Moreover, financial literacy is not related to simple decisions such as having a checking account (Christelis, Jappelli, and Padula 2010), but it is linked to complex portfolio decisions. For instance experimental studies in Mexico and Chile show that more financially literate individuals are more likely to choose pension accounts with lower administrative fees (Hastings and Tejeda-Ashton 2008; Hastings and Mitchell 2011; Hastings, Mitchell, and Chyn 2011). More financially sophisticated individuals are less affected by the choices of peers in their financial decisions (Bursztyn, Ederer, Ferman, and Yuchtman 2013)

A smaller subset of empirical studies has accounted for the endogeneity of financial literacy and also the fact that financial literacy may be measured with error. To this end, some authors use instrumental variables (IV) estimation to estimate the impact of financial literacy on financial behavior. For instance, van Rooij, Lusardi, and Alessie (2011) assess the relationship between financial literacy and stock market participation; their instruments are the financial experiences of siblings and parents, since these are arguably not under respondents' control. The authors report that instrumenting greatly enhances the measured positive impact of financial literacy on stock market participation. Christiansen, Joensen, and Rangvid (2008) use the opening of a new university in a local area as instrument for knowledge, and they conclude that economics education is an important determinant of investment in stocks. Other authors have used similar empirical strategies to estimate the effects of financial literacy on behavior. For example, Lusardi and Mitchell (2009) instrument financial literacy using the fact that different U.S. states mandated financial education in high school at different points in time and they interact these mandates with state expenditures on education. Bucher-Koenen and Lusardi (2011) use political attitudes at the regional level in Germany; the latter have a role in financial 
decision-making (for example, more free-market oriented supporters are more likely to invest in stocks, and the assumption is that individuals can learn from others around them). Interestingly, in all these cases, the IV financial literacy estimates are always larger than the ordinary least squares estimates, suggesting that the effect of financial literacy reported by many authors may be an underestimate of the true effect.

One might worry that other omitted variables might still influence financial decisions in ways that could bias results. For example, unobservables such as discount rates (Meier and Sprenger 2008), IQ (Grinblatt, Keloharju, and Linnainmaa 2011), or cognitive abilities can influence saving decisions and portfolio choice (Delavande, Rohwedder, and Willis 2008; Korniotis and Kumar 2011). Yet the analysis of panel data by Alessie, Van Rooij, and Lusardi (2011) using both fixed-effect regression and IV estimation continues to confirm the positive effect of financial literacy on retirement planning.

Turning to efforts to judge the effect of financial literacy on wealth accumulation, Behrman, Mitchell, Soo, and Bravo (2012) evaluate the effects of financial literacy of respondents of all ages on wealth holdings, and they employ several instruments including exposure to a new educational voucher system in Chile to isolate the causal effects of financial literacy and schooling attainment on wealth. Their results show that both financial literacy and schooling attainment are positively and significantly associated with wealth outcomes. Moreover, their IV estimates indicate even more potent effects of financial literacy on wealth than suggested by ordinary least-squares regression estimates. Similar findings are reported in van Rooij, Lusardi, and Alessie (2012), which also report potent effects of financial literacy on wealth using IV estimates. 
A different way of estimating the effects of financial literacy on economic outcomes has been to use field experiments, in which one group of individuals (the treatment group) is exposed to a financial education program and then their behavior is compared to a second group not thus exposed (the control group). These studies are discussed in detail in a later section of this paper; for now, it suffices to note that even in countries with less developed financial markets and pension systems, financial literacy impacts are similar to those found when examining the effect of financial literacy on retirement planning and pension participation (Lusardi and Mitchell 2011c). For example, Song (2011) shows that learning about interest compounding produces a sizeable increase in pension contributions in China.

The financial crisis has also provided a laboratory to study the effects of financial literacy against a backdrop of economic shocks. For example, when stock markets dropped sharply around the world, investors were exposed to large losses in their portfolios. This combined with much higher unemployment has made it even more important to be savvy in managing limited resources. Bucher-Koenen and Ziegelmeyer (2011) examine the financial losses experienced by German households during the financial crisis and confirm that the least financially literate were more likely to sell assets that had lost value, thus locking in losses. In Russia, Klapper, Lusardi, and Panos (2012) find that the most financially literate are significantly less likely to report having experienced diminished spending capacity and have more available saving. Additionally, estimates in different time periods suggest that financial literacy better equips individuals to deal with macroeconomic shocks.

Financial literacy has been found to affect not only the asset side of the household balance sheet, but also the liability side; indeed, here some of the strongest effects of financial literacy may be found. As financial markets opened up over the past two decades, people gained 
unprecedented access to credit and borrowing opportunities; this in turn demanded more financial savvy since interest rates charged on debt are normally higher than interest paid on saving. Moreover, high-cost methods of borrowing have proliferated over time. ${ }^{25}$ Some researchers focus on what they call peoples' financial 'mistakes,' as in Agarwal, Driscoll, Gabaiz, and Laibson (2009). The large number of mortgage defaults during the financial crisis has likewise suggested to some that debt and debt management is a fertile area for mistakes. For instance, recent surveys suggest that many borrowers do not know what interest rates are charged on their credit cards or mortgages (Moore 2003; Lusardi 2011; Disney and Gathergood 2012).

While much research documents correlations between financial literacy and behavior toward debt, it is again important to correct for the potential endogeneity of financial literacy as well as the problem of measurement error. Most studies to date have not done so, suggesting a possible avenue for future research. Moore (2003) reports that the least financially literate are also more likely to have costly mortgages; this pattern is reiterated by Gerardi, Goette, and Meier (2010) who further show that those with low numeracy are more likely to default on subprime mortgages. Campbell (2006) points out that those with lower income and less education (characteristics strongly related to financial illiteracy) are less likely to refinance their mortgages during a period of falling interest rates. Stango and Zinman (2009) conclude that those unable to correctly calculate interest rates out of a stream of payments end up borrowing more and accumulating less wealth. Lusardi and Tufano (2009a) confirm that the least financially savvy incur high transaction costs, paying higher fees and using high-cost borrowing. In their study, the less knowledgeable also report their debt loads as excessive, or that they are unable to judge their debt positions. Mottola (2012) finds that women with low financial literacy are more likely than

\footnotetext{
${ }^{25}$ The alternative financial services (AFS) industry has experienced tremendous growth in the United States: in 2009 , the Federal Deposit Insurance Corporation estimated the industry to be worth at least $\$ 320$ billion in terms of transactional services (FDIC 2009).
} 
men to engage in costly credit card behavior, and Utkus and Young (2011) conclude that the least literate are also more likely to borrow against their $401(\mathrm{k})$ and pension accounts. Lusardi and de Bassa Scheresberg (2012) examine those who undertake high-cost borrowing in the U.S., including payday loans, pawn shops, auto title loans, refund anticipation loans, and rent-to-own shops. Those who are less financially literate are substantially more likely to use high-cost methods of borrowing. Similar patterns arise in the U.K. where Disney and Gathergood (2012) report that consumer credit customers systematically underestimate the cost of borrowing, while the least financially literate have higher average debt-to-income ratios.

Research on both stock holdings and high-cost methods of borrowing involving the potential for high returns or high costs has suggested that educational attainment can be quite influential. For example, those with a college degree are more likely to own stocks and less prone to use high-cost borrowing (Haliassos and Bertaut 1995; Campbell 2006; Lusardi and de Bassa Scheresberg 2012). Similarly, there is a very strong correlation between education and wealth-holding (Bernheim and Scholz 1993). For our purposes, however, it is important to note that controlling for educational attainment in empirical models of stock holding, wealth accumulation, and high-cost methods of borrowing, does not diminish the statistical significance of financial literacy, while often it enhances it (Lusardi and Mitchell 2011b; Behrman, Mitchell, Soo, and Bravo 2012; van Rooij, Lusardi, and Alessie 2011, 2012; Lusardi and de Bassa Scheresberg 2012). Evidently, both general knowledge (education) and more specialized knowledge (financial literacy) both contribute to more informed financial decision-making. Accordingly, investment in financial knowledge appears to be a specific form of human capital.

Similarly, recognizing that financial literacy may be an important skill in an aging population, some authors have also linked financial literacy to demand for on-the-job training 
(Clark, Ogawa, and Matsukura 2010). Others have examined financial vulnerability and looked at the potential link with financial literacy (Lusardi, Schneider, and Tufano 2011). These are all potential avenues for future work.

\section{Costs of Financial Ignorance Pre-retirement}

In the wake of the financial crisis, many have become interested in the costs of financial illiteracy as well as its distributional impacts. For instance, financial literacy can explain more than half the wealth inequality observed in U.S. data (Lusardi, Michaud, and Mitchell 2013). In the Netherlands, van Rooij, Lusardi, and Alessie (2011) estimate that being in the $75^{\text {th }}$ versus the $25^{\text {th }}$ percentile of the financial literacy index equals around $€ 80,000$ in terms of differential net worth (i.e., roughly 3.5 times the net disposable income of a median Dutch household). They also point out that an increase in financial literacy from the $25^{\text {th }}$ to the $75^{\text {th }}$ percentile for an otherwise average individual is associated with a 17-30 percentage point higher probability of stock market participation and retirement planning, respectively. For this reason, if the effects of financial literacy on financial behavior can be taken as causal, the costs of financial ignorance are substantial.

In the U.S., investors are estimated to have foregone substantial equity returns due to fees, expenses, and active investment trading costs, in an attempt to 'beat the market.' French (2008) calculates that this amounts to an annual total cost of around $\$ 100$ billion which could be avoided by passively indexing. Since the least financially literate are unlikely to be sensitive to fees, they are likely to bear such costs disproportionately. Additionally, many of the financially illiterate have been shown to shun the stock market, which Cocco, Gomes, and Maenhout (2005) suggest can impose welfare losses amounting to 4 percent of wealth. The economic cost of under-diversification computed by Calvet, Campbell, and Sodini (2007) is also substantial: they 
conclude that a median investor in Sweden experienced an annual return loss of 2.9 percent on a risky portfolio, or 0.5 percent of household disposable income. But for one in 10 investors, these annual costs were much higher, 4.5 percent of disposable income.

Costs arise not only in the saving and investment arena, but also in the way that consumers manage their liabilities. Campbell (2006) reports that suboptimal refinancing among U.S. homeowners resulted in $0.5-1$ percent per year higher mortgage interest rates, or in aggregate, $\$ 50-100$ billion annually. And as noted above, the least financially savvy will be least likely to refinance their mortgages. Gerardi, Goette, and Meier (2010) show that numerical ability may have contributed substantially to the massive amount of defaults on subprime mortgages in the recent financial crisis. According to their estimates, those in the highest numerical ability grouping have about a 20 percentage point lower probability of defaulting on their subprime mortgages than those in the lowest financial numeracy group.

One can also link 'debt literacy' regarding credit card behaviors that generate fees and interest charges to paying bills late, going over the credit limit, using cash advances, and paying only the minimum amount due. Lusardi and Tufano (2009a) show that, while less knowledgeable individuals constitute only 29 percent of the cardholder population, they account for 42 percent of these charges. Accordingly, the least financially savvy bear a disproportionate share of the costs associated with fee-inducing behaviors. Indeed, the average fees paid by those with low knowledge are 50 percent higher than those paid by the average cardholder. And of these four types of charges incurred by the less-knowledgeable cardholders, one-third are incremental charges linked to low financial literacy. 
Another way that the financially illiterate spend dearly for financial services is via highcost forms of borrowing, including payday loans. ${ }^{26}$ While the amount borrowed is often low (\$300 on average), such loans are often made to individuals who have five or more such transactions per year (Center for Responsible Lending 2004). It turns out that these borrowers also frequently fail to take advantage of other, cheaper opportunities to borrow. Agarwal, Skiba, and Tobacman (2009) study payday borrowers who also have access to credit cards, and they find that two-thirds of their sample had at least $\$ 1,000$ in credit card liquidity on the day they took out their first payday loan. This points to a pecuniary mistake: given average charges for payday loans and credit cards and considering a two-week payday loan of $\$ 300$, the use of credit cards would have saved these borrowers substantial amounts - around \$200 per year (and more if they took out repeated payday loans). While there may be good economic reasons why some people may want to keep below their credit card limits, including unexpected shocks, Bertrand and Morse (2011) determine that payday borrowers often labor under cognitive biases, similar to those with low financial literacy (Lusardi and de Bassa Scheresberg 2012).

\section{Costs of Financial Ignorance in Retirement}

Our discussion of the impact of financial ignorance thus far has focused on how financial knowledge impacts key outcomes including borrowing, saving, and investing decisions during the worklife. Yet financial knowledge also appears to pay off later in life, during the retirement period. Given that people over the age of 65 hold more than $\$ 18$ trillion in wealth, ${ }^{27}$ this is an important issue.

\footnotetext{
${ }^{26}$ Americans paid about $\$ 8$ billion in finance charges to borrow more than $\$ 50$ billion from payday lenders in 2007 ; the annual interest rates on such loans are often very high, over 400\%. See Bertrand and Morse (2011) and the references therein.

${ }^{27}$ See for instance Laibson (2011).
} 
Above we noted that financial literacy is associated with greater retirement planning and greater retirement wealth accumulation. ${ }^{28}$ Hence it stands to reason that the more financially savvy will likely be better financially endowed when they do retire. A related point is that the more financially knowledgeable are also better informed about pension system rules, pay lower investment fees in their retirement accounts, and diversify their pension assets better (Arenas de Mesa, Bravo, Behrman, Mitchell, and Todd 2008; Chan and Stevens 2008; Hastings, Mitchell, and Chyn 2011). ${ }^{29}$ To date, however, relatively little has been learned about whether more financially knowledgeable older adults are also more successful at managing their resources in retirement.

This is a particularly difficult set of decisions, since retirees must look ahead to a future of uncertainty when making irrevocable choices with far-reaching consequences. For instance, people must forecast their (and their partner's) survival probabilities, investment returns, pension income, and medical and other expenditures. Moreover, many of these financial decisions are once-in-a-lifetime events, including when to retire and claim one's pension and Social Security benefits. Accordingly, it would not be surprising if financial literacy enhanced peoples' ability to make these important decisions later in life.

This question is especially relevant when it comes to the decision of whether retirees purchase lifetime income streams with their assets, since by so doing, they insure themselves

\footnotetext{
${ }^{28}$ See for instance Ameriks, Caplin, and Leahy (2003); van Rooij, Lusardi, and Alessie (2012); and Lusardi and Mitchell (2007a, b; 2009). It is worth noting that education also plays a role, as pointed out by Poterba, Venti, and Wise (2013) who find a substantial association between education and the post-retirement evolution of assets. For example, for two-person households, assets growth between 1998 and 2008 was greater for college graduates than for those with less than a high school degree, producing over $\$ 600,000$ in assets for the richest quintile, to $\$ 82,000$ for the lowest asset quintile. As in the theoretical model described previously, households with different levels of education will invest in different assets, allowing them to earn different rates of return. It remains to be seen whether this is because of differential financial literacy investments, or simply due to general knowledge gleaned through education.

${ }^{29}$ Gustman, Steinmeier, and Tabatabai (2010) note that financial knowledge is not the same thing as cognitive functioning, since the latter is not associated with greater knowledge of retirement plan rules.
} 
from running out of income in old age. ${ }^{30}$ Nevertheless, despite the fact that this form of longevity protection is very valuable in theory, relatively few payout annuities are purchased in practice in virtually every country (Mitchell, Piggott, and Takayama 2011). This is partly because people have been shown to be susceptible to framing and default effects (Agnew and Szkyman 2011; Brown, Kapteyn, and Mitchell 2013). This conclusion is corroborated and extended by Brown, Kapteyn, Luttmer, and Mitchell (2011), who demonstrate experimentally that people value annuities less when they are offered the opportunity to buy additional income streams, but the same people value annuities more if offered a chance to exchange their annuity flows for a lump sum. ${ }^{31}$ Importantly for the present purpose, the financially savvy provide more consistent responses across alternative ways of eliciting preferences. By contrast, the least financially literate give inconsistent results and respond to irrelevant cues when presented with the same set of choices. In other words, financial literacy appears to be highly influential in helping older households equip themselves with longevity risk protection in retirement.

Much more must be learned about how peoples' financial decision-making abilities change with age, and how these are related to financial literacy. For instance, Agarwal, Driscoll, Gabaix, and Laibson (2009) report that the elderly pay much more than the middle-aged for 10 financial products. ${ }^{32}$ Thus the 75 -year-olds in their sample pay about $\$ 265$ more per year for home equity lines of credit than do the 50 -year-olds. How this varies by financial literacy is not

\footnotetext{
${ }^{30}$ Several authors have also linked financial literacy and knowledge about retirement saving. For instance, Agnew, Szykman, Utkus, and Young (2007) show that employees who were the least financially knowledgeable were 34 percent less likely to participate voluntarily, and 11 percent less likely to be automatically enrolled, in their in their company's 401(k) plan.

${ }^{31}$ These findings are not attributable to differences in individuals' subjective life expectancies, discount rates, risk aversion, borrowing constraints, political risk, or other conventional explanations (Brown, Kapteyn, Luttmer, and Mitchell 2011).

${ }^{32}$ These include credit card balance transfers; home equity loans and lines of credit; auto loans; credit card interest rates; mortgages; small business credit cards; credit card late-payment fees; credit card over-limit fees; and credit card cash-advance fees.
} 
yet known, but it might be that those with greater baseline financial knowledge are better protected as they move into the second half of their lifetimes. ${ }^{33}$

Given the substantial evidence on the likely costs of financial illiteracy, we turn next to financial education programs and examine what works.

\section{Assessing the Effects of Financial Literacy Programs}

Financial education programs in the U.S. and elsewhere have been implemented over the years in a variety of settings -- in schools, the workplace, libraries, and sometimes targeting specific subgroups of the population. As one example, several U.S. states mandated financial education in high school at different points in time, generating 'natural experiments' studied by Berhneim, Garrett, and Maki (2001). Similarly, financial education in high schools has recently been piloted and studied in several countries including Brazil and Italy (Bruhn, Legovini, and Zia 2012; Romagnoli and Trifilidis 2012). In some cases, large U.S. firms have launched financial education programs including those examined by Bernheim and Garrett (2003), Clark and D'Ambrosio (2008), and Clark, Morrill, and Allen (2011, 2012). Often the employer's intention is to boost DC plan saving and participation (Duflo and Saez 2003, 2004; Lusardi, Keller, and Keller 2008; Goda, Manchester, and Sojourner 2012). Programs have also been adopted for especially vulnerable groups such as those in financial distress (Collins and O’Rourke 2010).

Over the years a handful of authors have sought to summarize the impacts of financial education programs. ${ }^{34}$ Rather than detailing all of the studies covered there, we instead highlight

\footnotetext{
${ }^{33}$ This could be particularly important inasmuch as Korniotis and Kumar (2011) find that cognitive decline is fastest with age for the less educated, lower earners, and minority racial/ethnic groups.

${ }^{34}$ See for instance Collins and O'Rourke (2010); Gale, Harris and Levine (2012); Hastings, Madrian, and Skimmyhorn (2012); Hathaway and Khatiwada (2008); Lusardi and Mitchell (2007b); Lyons, Palmer, Jayaratne, and Scherpf (2006); and Martin (2007). Hira (2010) provides a broad overview of research on financial education over a long time span.
} 
the key issues which future researchers must take into account when evaluating the effectiveness of financial education programs. ${ }^{35}$ We also touch on key recent research not reviewed in prior surveys.

A concern emphasized in Section 2, above, is that evaluation studies are sometimes conducted in the absence of a theoretical model explaining how financial knowledge is developed. That is, if we define financial literacy as a form of human capital investment, it stands to reason that some will find it optimal to invest in financial literacy but others will not. Accordingly, if a program were to be judged based on specific behavioral changes such as increasing retirement saving or participation in retirement accounts, it must be recognized that the program is both theoretically and practically unlikely to change everyone's behavior in the same way. ${ }^{36}$ For example, a desired outcome from a financial education program might be to boost saving. Yet for some, it may not be optimal to save; instead, such persons might rationally reduce their debt. Unless an evaluator focuses on this larger concept of saving, however, a program might be (incorrectly) judged a failure.

A related concern is that, since such a large portion of the population is not financially knowledgeable about the basic concepts of interest compounding, inflation, and risk diversification, it is unlikely that short exposure to financial literacy training would make much of a dent in consumers' decision-making prowess. For this reason, offering a few retirement seminars or sending employees to a benefit fair may be judged as relatively ineffective (Duflo and Saez 2003, 2004). Moreover, this raises the issue of cost-benefit considerations, which to date have rarely been undertaken in the field. It is also worth remembering that the root causes

\footnotetext{
${ }^{35}$ Two good discussions by Fox, Bartholomae, and Lee (2005) and Lyons and Neelakantan (2008) highlight the limitations of existing financial education program evaluations.

${ }^{36}$ Moreover, practitioner discussions often equate success as 'financial capability,' a term often identified with behavior change rather than knowledge.
} 
of financial illiteracy still must be better understood: for instance, the sex gap in financial literacy still requires additional explanation.

The evidence reported previously also shows there is vast heterogeneity, both in financial behavior and also in financial literacy. Rarely do programs account for such important baseline differences, yet programs that target specific groups are likely to be more effective than one-sizefits-all financial education programs. For example, Lusardi, Michaud and Mitchell (2013) show that there is substantial heterogeneity in individual behavior so that given the costs and benefits of financial literacy, not everyone would gain from financial education. Thus we should not expect a 100 percent participation rate in financial education programs. That is, people differ one from another, and they have different preferences and economic circumstances. Accordingly, saving should optimally be at zero (or negative) sometimes, and financial education programs in this case would not be expected to change that behavior. In this respect, the model delivers an important prediction: in order to change behavior, financial education programs must be targeted to specific groups of the population.

As in other fields of economic research, program evaluations must be rigorous if they are to persuasively establish causality and effectiveness. As noted by Collins and O'Rourke (2010), the 'golden rule' of evaluation is the experimental approach in which a 'treatment' group exposed to financial literacy education is compared with a 'control' group that is not (or that is exposed to a different treatment). Thus far, unfortunately, few financial educational programs have been designed or evaluated with these standards in mind, making it difficult to draw inferences.

A related point is that confounding factors may bias estimated impacts unless the evaluation is carefully structured. As an example, we point to the debate over the efficacy of 
teaching financial literacy in high school, a discussion that will surely be fed by the new financial literacy module in the 2012 PISA mentioned above. Some have argued against financial education in school (e.g., Willis 2008), drawing on the findings from the Jump\$tart Coalition for Personal Financial Literacy (Mandell 2004, 2008). The Jump\$tart studies concluded that students scored no better in financial literacy tests even if they attended school in states having financial education; in fact, in some cases, Mandell $(1997,2008)$ found that they scored even worse than students in states lacking these programs. Yet subsequent analyses (see Walstad, Rebeck, and MacDonald 2010) and the references therein) point out that this research was incomplete, since it did not account for course content, test measurement, teacher preparation, and amount of instruction. These points are underscored by Tennyson and Nguyen (2001) who revisit the Jump\$tart analysis by looking more closely at state education requirements for personal finance education. They conclude that when students are mandated to take a financial education course, they perform much better than students in states with no personal finance mandates. Accordingly, there is reason to believe that mandating personal finance education may, in fact, be effective in increasing student knowledge -- but only when it requires significant exposure to personal finance concepts.

It is likewise risky to draw inferences without knowing about the quality of teaching in these courses. For instance, Way and Holden (2009) examine data from more than 1,200 K-12 teachers, prospective teachers, and teacher education faculty representing four census regions, along with teachers' responses to questions about their personal and educational backgrounds in financial education. Almost all of the teachers recognized the importance of and need for financial education, yet fewer than one-fifth stated they were prepared to teach any of the six personal finance concepts normally included in the educational rubrics. Furthermore, prospective 
teachers felt least competent in the more technical topics including risk management and insurance, as well as saving and investing. Interestingly, these are also the concepts that the larger adult population struggles with, as noted above. That study concludes that state education mandates appear to have no effect on whether teachers take courses in personal finance, teach the courses, or feel competent to teach such a course, consistent with the fact that the states mandating high school financial education do not necessarily provide or promote teacher training in the field.

One might also investigate whether the knowledge scores tested actually measure what is taught in school and whether students self-select into financial education classes. Walstad, Rebeck, and MacDonald (2010) use a quasi-experimental set up to assess a well-designed video course covering several fundamental concepts for both students and teachers. The test they employ is aligned with what was taught in school and measures the initial level of understanding of personal finance so as to capture improvements in financial knowledge. Results indicate a significant increase in personal finance knowledge among the 'treated' students, suggesting that carefully crafted experiments can and do detect important improvements in knowledge. This is an area that certainly requires more research of the type proposed by Collins and O'Rourke (2010).

If anything, evaluating workplace financial education presents even greater problems. It does appear that employees who attend a retirement seminar are much more likely to save and contribute to pension accounts (Bernheim and Garrett 2003). Nevertheless, those who attend such seminars are unlikely to be randomly drawn from the entire working population. In other words, since attendance is voluntary, those who attend may already have a proclivity to save. Another problem is that researchers have often little or no information on the content and quality 
of the workplace seminars. A few authors have measured the information content of the seminars (Clark and D'Ambrosio 2008; Lusardi, Keller, and Keller 2008); they also conduct pre- and postevaluations to detect behavioral changes or intentions to change future behavior. Their findings suggest that this information is very valuable in assessing programs. One notable recent experiment involved exposing a representative sample of the U.S. population to short videos explaining several fundamental concepts including the power of interest compounding, inflation, risk diversification, the topics that most people fail to comprehend (Heinberg, Hung, Kapteyn, Lusardi, and Yoong 2010). Compared to a control group that did not receive such education, those exposed to the informational videos were more knowledgeable and better able to answer hypothetical questions about saving decisions. ${ }^{37}$ Thus, while more research is needed, it seems that when researchers target concepts using carefully-designed experiments, they are likely to detect changes in knowledge and behavior critical for making financial decisions.

It is often difficult to evaluate empirically how actual workers' behavior changes after an experimental treatment of the type just discussed. Goda, Manchester, and Sojourner (2012) ask whether employee decisions to participate in and contribute to their company retirement plan is affected by information about the correlation between retirement savings and post-retirement income. This is a difficult concept for many, as the computation involves complex relationships between contributions, investment returns, retirement ages, and longevity. In that study, employees were randomly assigned to a control and a treatment group; the treatment group received an information intervention while nothing was sent to the control group. The intervention contained a customized projection of the additional account balance and retirement

\footnotetext{
${ }^{37}$ The difference in the knowledge of risk diversification, tax benefits of retirement accounts, and the benefits of employers' matches between the two groups (measured by the proportion of correct answers) was on the order of 10 percentage points. While these videos were targeted to young adults, older respondents who viewed them also increased knowledge and capacity to correctly answer questions concerning saving decisions (Heinberg, Hung, Kapteyn, Lusardi, and Yoong, 2010).
} 
income that would result from additional hypothetical contribution amounts, customized based on the employee's current age. Results show that the treatment group members were more likely than the control group to boost their pension contributions and contribution rates; the increase was an additional 0.17 percent of salary. Moreover, the treatment group felt better informed about retirement planning and was more likely to have figured out how much to save. This experiment is notable in that it rigorously illustrates the effectiveness of interventions-even low-cost informational ones-in increasing pension participation and contributions. ${ }^{38}$

Very promising work assessing the effects of financial literacy has also begun to emerge from research in developing countries. Analysts often focus on people with very low financial literacy and in vulnerable subgroups which may have the most to gain. Many of these studies also use the experimental method described above, now standard in development economics research. These studies contribute to an understanding of the mechanisms driving financial literacy as well as economic advances for financial education program participants. One example, by Carpena, Cole, Shapiro, and Zia (2011), seeks to disentangle how financial literacy programs influence financial behavior. The authors use a randomized experiment on low income urban households in India who underwent a five-week comprehensive video-based financial education program with modules on savings, credit, insurance and budgeting. They conclude that financial education in this context did not increase respondent numeracy, perhaps not surprisingly given that only 4 percent of respondents had a secondary education. Nevertheless, financial education did positively influence participant awareness of and attitudes toward financial products and financial planning tools. In a related study, Cole, Giné, Tobacman, Topalova, Townsend, and Vickery (2013) find that demand for rainfall insurance is higher in

\footnotetext{
${ }^{38}$ A discussion of successful strategies to improve financial literacy and financial education programs is provided in Crossan (2011)
} 
villages where individuals were more financially literate. Song (2011) shows that when Chinese farmers are taught about interest compounding, it produces a sizeable increase in pension contributions. ${ }^{39}$

In sum, while much effort has been devoted to examining the effectiveness of financial education programs in a variety of settings, relatively few studies have been informed by either a suitable theoretical model or a carefully-designed empirical approach. And since the theory predicts that not everyone will invest in financial knowledge, it is unreasonable to expect all 'treated' by a program will dramatically change their behavior. Moreover, a short program that is not tailored to specific groups' needs is unlikely to make much difference. For these reasons, future analysts would do well to emulate the more recent rigorous field experiments that trace how both knowledge and behavior changes result from additional purpose-designed financial information and training.

\section{Implications and Discussion}

As we have shown, a relatively parsimonious set of questions measuring basic concepts such as interest compounding, inflation, and risk diversification has now become the starting point for evaluating levels of financial literacy around the world. Using these questions, researchers have demonstrated that low levels of financial knowledge are pervasive, suggesting that it will be quite challenging to provide the tools to help people function more effectively in complex financial and credit markets requiring sophisticated financial decision-making. While research in this field continues to spread, it seems clear that there are likely to be important benefits of greater financial knowledge, including savvier saving and investment decisions,

\footnotetext{
39 A broad perspective on how financial education programs can be made more effective in developing countries is
} available in Holtzman (2011). 
better debt management, more retirement planning, higher participation in the stock market, and greater wealth accumulation. Though it is challenging to establish a causal link between financial literacy and economic behavior, both instrumental variables and experimental approaches suggest that financial literacy does play a role in influencing financial decision making, and the causality goes from knowledge to behavior.

Much work remains to be done. Very importantly, there has been no carefully-crafted cost-benefit analysis indicating which sorts of financial education programs are most appropriate, and least expensive, for which kinds of people. Some research from developing countries speaks to this point, comparing educational treatments with other approaches such as simplifying decisions (Cole, Sampson, and Zia 2011; Drexel, Fischer, and Schoar 2011), but this remains a high priority area. Nevertheless, the estimated aggregate costs of financial illiteracy point to possibly high returns, especially in the areas of consumer debt and debt management.

A related issue has to do with which sorts of problems are best suited to remedying through financial education, versus removing choice options from consumers' menus altogether or simplifying the options that people face. In this vein, Thaler and Sunstein (2010) have emphasized the importance of devoting careful attention to the design of the environments in which people make choices, or the so-called 'choice architecture.' An important example arises in the context of employer-provided pensions which in the past left it to individual employees to decide whether to save and how to invest their defined contribution contributions. When employers automatically enroll workers into these plans rather than let them opt in, this can dramatically increase pension participation (from under 40 percent to close to 90 percent; Madrian and Shea 2001). Several other studies have also reported that automatic enrollment leads to large and persistent increases in pension participation (Choi, Laibson, and Madrian 
2004; Choi, Laibson, Madrian and Metrick 2006; Thaler and Benartzi 2004), and better diversified portfolios (Mitchell and Utkus 2012).

In the wake of the recent financial crisis, attention has been increasingly devoted to methods of protecting people from their own financial illiteracy and inability to make informed financial decisions. Indeed there is substantial concern that consumers may not be sophisticated enough to appreciate and take advantage of the many opportunities offered by complex financial markets and hence they may easily fall prey to scams (Deevy, Lucich, and Beals 2012). The Dodd-Frank Act of 2010, establishing the U.S. Consumer Financial Protection Bureau, had as a key goal the development of a government entity that could better protect consumers and specify uniform standards for financial products. ${ }^{40}$

In our view, there is room for improvement in both the choice architecture approach and the effort to educate people about financial basics. As Thaler, Sunstein, and Balz (2010: np) note: 'choice architects do not always have the best interests of the people they are influencing in mind.' Moreover, expanding automatic enrollment to the decumulation phase for example by having automatic annuitization of pensions upon retirement - a topic of some interest recently in policy circles - may be deleterious to some, who would have to cut consumption during their worklives and render them ineligible for government benefit programs after retirement (such as Medicaid or Supplemental Security Income). Plan sponsors also have avoided high saving rates targets in their default auto-enrollment arrangements. For instance, the auto-enrollment contribution rate for new hires was set at 3 percent of salary in the company studied by Madrian and Shea (2001). But at that firm, a 6 percent contribution rate would entitle the worker to receive a 50 percent employer match; in other words, the low default rate did not enable workers

\footnotetext{
${ }^{40}$ Among other things, the Bureau's mandate is to promote financial education and monitor financial markets for new risks to consumers; see http://www.consumerfinance.gov/the-bureau/.
} 
to take full advantage of the employer's match. ${ }^{41}$ Of additional concern is the fact that the employer's 3 percent default rate was taken by existing employees as a signal of a suggested target saving level, since many of them reduced their contributions to 3 percent as well. Additional examples of people acting as though the default were the employer-endorsed target include a study by Beshears, Choi, Laibson, and Madrian (2012), who show that workers tend to stick to the 'wrong' default for long periods of time. Interestingly, those likely to do so are disproportionately low income and less educated - factors correlated with low financial literacy.

As noted in Section 2, above, the human capital approach to financial literacy suggests that there will be substantial heterogeneity in both financial knowledge and economic behavior, so it is unlikely that a single default rate or environment will enhance individual wellbeing. For example, when workers are carrying credit card debt or high-interest mortgages, it may be more sensible to pay off these debts rather than raise their pension contributions. Similarly, borrowing from one's 401(k) may be more cost-effective for financially strapped households, compared to taking out higher-cost debt elsewhere (Lu, Mitchell, and Utkus 2010). Additionally, only about half of the U.S. workforce is employed at firms that offer pensions, so for the remaining several million employees, automatic enrollment in company-based plans will be unable to boost saving rates for those untouched by this system.

An alternative method of enhancing peoples' performance in an increasingly financially complex world might be to outsource the job: to rely on financial advisors. Yet in the U.S., only a small fraction of households currently consults financial advisors, bankers, certified public accountants, or other such advice professionals, with most still relying on informal sources of advice. Even among those who indicate they might be willing to use professional investment

\footnotetext{
${ }^{41}$ Note, however, that when left to their own devices, many employees simply fail to enroll in pensions and hence fail to exploit the employer match at all, if or when one is available.
} 
advice, two-thirds state they would probably implement only the recommendations in line with their own ideas (Employee Benefit Research Institute 2007). In other words, financial advice may not have much of an impact if individuals fail to seek out and act on the recommendations of their advisors. Additionally, there are many different types of 'advice professional' credentials, each regulated by different private and/or public sector entities. As Mitchell and Smetters (2013) point out, it is often difficult or even impossible for consumers to determine whether the quality of advice provided is accurate, suitable, and consistent with their own goals. Moreover, existing compensation structures may not well-align households' and advisors' interests. And those least likely to be knowledgeable may also face obstacles in identifying good advice sources: indeed Collins (2011) and Finke (2013) suggest that financial literacy and financial advice may be complements rather than substitutes. ${ }^{42}$

Finally, relatively little is known about the effects of financial advice and whether it can improve financial decision-making. Some preliminary evidence suggests that financial counseling can be effective in reducing debt levels and delinquency rates (Agarwal, Amromin, Ben-David, Chomsisengphet, and Evanoff 2011; Collins and O'Rouke 2010; Elliehausen, Londquist, and Staten 2007; and Hirad and Zorn 2002). In practice, most people continue to rely on the help of family and friends for their financial decisions, particularly among those with low education.

If, as argued previously, saving decisions are very complex, one way to help people save may be to find ways to simplify those decisions. For example, it could be useful to find ways to ease people into action. Such a strategy is analyzed by Choi, Laibson, and Madrian (2004), who studied the effects of Quick Enrollment, a program that gives workers the option of enrolling in the employer-provided saving plan by opting into a preset default contribution rate and asset

\footnotetext{
${ }^{42}$ A detailed analysis of the issues surrounding financial advice appears in Mitchell and Smetters (2013).
} 
allocation. Unlike defaults, workers have a choice of whether or not to enroll, but the decision is much simplified as they need not decide their contribution rates or how to allocate their assets. When new hires were exposed to the Quick Enrollment program, participation rates in 401(k) plans tripled, going from 5 percent to 19 percent in the first month of enrollment. When the program was offered to previously hired non-participants, participation increased by 10 to 20 percentage points. Moreover, Quick Enrollment proved popular among African-Americans and lower income workers (those earning less than $\$ 25,000$ ) who, as noted above, are less likely to be financially literate.

Another approach designed to simplify the decision to save and, in addition, motivate employees to make an active choice is discussed by Lusardi, Keller, and Keller (2008), who devised a planning aid distributed to new hires during employee orientation. This planning aid embodies several critical features. First, it breaks down the process of enrolling in supplementary pensions into several small steps, describing to participants what they need to do to be able to enroll online. It also provides several pieces of information to help overcome barriers to saving, such as describing the low minimum amount of income employees can contribute (in addition to the maximum) and indicating the default fund that the employer has chosen for them (a life-cycle fund). While their evaluation was not performed in an experimental setting, the study provides some useful insights. First, the qualitative data collected reveals important heterogeneity across employees, even within the same firm. Second, economic incentives such as employer matches or tax advantages do not exhaust the list of options to induce people to save. In fact, given peoples' lack of information and financial knowledge, there may be other, more cost-effective, programs that can encourage saving. Third, the authors conclude that employees are more prone to decision-making at some times rather than others. For example, starting a new job is a good 
time to think about saving, often because people must make decisions about their pension contributions.

In the developing countries as well, much work is needed to assess whether simplification can help individuals make financial decisions, spanning from using rather simple financial instruments, such as checking accounts, to more complex contracts, such as insurance, or decisions related to entrepreneurial activities. Early research is promising: Drexel, Fischer, and Schoar (2011) show that a simplified rule-of-thumb training program enhanced business practices and outcomes among microentrepreneurs in the Dominican Republic. Kast, Meier, and Pomeranz (2012) also find that self-help peer groups and text messaging boosted employee saving patterns in Chile.

\section{Conclusions and Remaining Questions}

In the wake of the global financial crisis, policymakers around the world have expressed deep concern about widespread gaps in financial knowledge. Also, efforts are underway to fill these gaps with specific programs to 'identify individuals who are most in need of financial education and the best ways to improve that education' (OECD 2005, 2007). The U.S. President's Advisory Council on Financial Literacy (PACFL 2008, np) has stated that 'far too many Americans do not have the basic financial skills necessary to develop and maintain a budget, to understand credit, to understand investment vehicles, or to take advantage of our banking system. It is essential to provide basic financial education that allows people to better navigate an economic crisis such as this one.' U.S. Federal Reserve Board Chairman Bernanke (2011: 2) has similarly opined: 'In our dynamic and complex financial marketplace, financial education must be a life-long pursuit that enables consumers of all ages and economic positions 
to stay attuned to changes in their financial needs and circumstances and to take advantage of products and services that best meet their goals. Well-informed consumers, who can serve as their own advocates, are one of the best lines of defense against the proliferation of financial products and services that are unsuitable, unnecessarily costly, or abusive.'

Despite policymaker agreement on the need to fill these gaps, there is still much to learn about the most cost-effective ways to build financial knowledge in the population at large. The literature to date has showed that, around the world, many people are financially illiterate. Econometric models and experiments have done much to confirm the causal impact of financial literacy on economic decision-making, and to separately identify this effect from other factors, including education. Research on efforts to enhance financial literacy suggest that some interventions work well, but additional experimental work is needed to explore endogeneity and establish causality.

Nonetheless, several tasks remain. First, theoretical models of saving and financial decision-making can be further enriched to incorporate the fact that financial knowledge is a form of human capital. Second, efforts to better measure financial education are likely to pay off, including gathering information on teachers, training programs, and material covered. Third, outcomes beyond what have been studied to date are likely to be of interest, including, for instance, borrowing for student loans, investment in health, reverse mortgage patterns, and when to claim Social Security benefits, decisions that all have far-reaching economic consequences. Additional work is also needed to learn more about the directions of causality between financial knowledge and economic wellbeing, though the early results offered here are promising. It also appears that more and careful field experiments and cross-national research might be useful in learning more about the financially illiterate and drawing out the causal links between financial 
knowledge, costs, and benefits. While the costs of raising financial literacy are likely to be substantial, so too are the costs of being liquidity-constrained, over-indebted, and poor, in retirement. 


\section{References}

Agarwal, Sumit, Gene Amromin, Itzhak Ben-David, Souphala Chomsisengphet, and Douglas Evanoff. 2011. Financial Counseling, Financial Literacy, and Household Decisionmaking. In Financial Literacy: Implications for Retirement Security and the Financial Marketplace. Eds. O.S. Mitchell and A. Lusardi. Oxford: Oxford University Press: 181-205.

Agarwal, Sumit, John Driscoll, Xavier Gabaix, and David Laibson. 2009. The Age of Reason: Financial Decisions over the Lifecycle with Implications for Regulation, Brookings Papers on Economic Activity. Fall: 51-101.

Agarwal, Sumit, Paige Skiba, and Jeremy Tobacman. 2009b. Payday Loans and Credit Cards: New Liquidity and Credit Scoring Puzzles? Wharton School Working Paper, University of Pennsylvania.

Agnew, Julie, Hazel Bateman and Susan Thorp. 2012. Financial Literacy and Retirement Planning in Australia. University of New South Wales Working Paper.

Agnew, Julie, and Lisa Szykman. 2011. Annuities, Financial Literacy and Information Overload. In Financial Literacy: Implications for Retirement Security and the Financial Marketplace. Eds O. S. Mitchell and A. Lusardi. Oxford: Oxford University Press: 158178.

Agnew, Julie, Lisa Szykman, Stephen Utkus, and Jean Young. 2007. Literacy, Trust and 401(k) Savings Behavior. Center for Retirement Research Working Paper 2007-10. Boston College.

Alessie, Rob, Maarten van Rooij, and Annamaria Lusardi. 2011. Financial Literacy and Retirement Preparation in the Netherlands. Journal of Pension Economics and Finance 10(4): 527-545.

Almenberg, Johann and Anna Dreber. 2011. Gender, Financial Literacy, and Stock Market Participation. Stockholm School of Economics Working Paper.

Almenberg, Johann, and Olof Widmark. 2011. Numeracy, Financial Literacy, and Participation in Asset Markets. Swedish Ministry of Finance Working Paper.

Ameriks, John, Andrew Caplin, and John Leahy. 2003. Wealth Accumulation and the Propensity to Plan. Quarterly Journal of Economics 118: 1007-1047.

Arenas de Mesa, Alberto, David Bravo, Jere R. Behrman, Olivia S. Mitchell, and Petra E. Todd. 2008. The Chilean Pension Reform Turns 25: Lessons from the Social Protection Survey. In Lessons from Pension Reform in the Americas. Eds. S. Kay and T. Sinha. Oxford: Oxford University Press: 23-58.

Arrondel, Luc, Majdi Debbich, and Frédérique Savignac. 2012. Stockholding and Financial Literacy in the French Population. International Journal of Social Sciences and Humanity Studies. 4(2): 1309-8063

Ashraf, Nava, Diego Aycinena, Claudia Martinez A., and Dean Yang. 2011. Remittances and the Problem of Control: A Field Experiment Among Migrants from El Salvador. University of Michigan Working Paper.

Atkinson, Adele and Flore-Anne Messy. 2012. Measuring Financial Literacy: Results of the OECD/International Network on Financial Education (INFE) Pilot Study. OECD Working Papers on Finance, Insurance and Private Pensions, No. 15. 
Attanasio, Orazio and Guglielmo Weber. 2010. Consumption and Saving: Models of Intertemporal Allocation and Their Implications for Public Policy. Journal of Economic Literature 48: 693-751.

Banks, James, and Zoe Oldfield. 2007. Understanding Pensions: Cognitive Functions, Numerical Ability and Retirement Saving, Fiscal Studies 28 (2).

Bateman, Hazel, Christine Ebling, John Geweke, Jordan Louviere, Stephen Satchell, and Susan Thorp. 2011. Financial Literacy, Retirement Savings and Expectations Formation: Evidence from Australia. Centre for Pensions and Superannuation Working Paper, University of New South Wales, Australia.

Becker, Gary S. 1975. Human Capital: A Theoretical and Empirical Analysis. $2^{\text {nd }}$ Ed. New York: Columbia University Press.

Behrman, Jere, Olivia S. Mitchell, Cindy Soo, and David Bravo. 2012. Financial Literacy, Schooling, and Wealth Accumulation. American Economic Review. 102(3): 300-304.

Benítez-Silva, Hugo, Berna Demiralp and Zhen Liu. 2009. Social Security Literacy and Retirement Well-Being. MRRC Working Paper 2009-210.

Ben-Porath, Yoram. 1967. The Production of Human Capital and the Life Cycle of Earnings. Journal of Political Economy. 75(4): 352-365.

Bernanke, Ben S. 2011. Statement of the Chairman of the Board of Governors of the Federal Reserve System at a Hearing conducted by the Subcommittee on Oversight of Government Management, the Federal Workforce, and the District of Columbia of the Committee on Homeland Security and Governmental Affairs, U.S. Senate, Washington, D.C. (April 12).

Bernheim, Douglas. 1995. Do Households Appreciate their Financial Vulnerabilities? An Analysis of Actions, Perceptions, and Public Policy. In Tax Policy and Economic Growth. Washington, DC: American Council for Capital Formation: 1-30.

Bernheim, Douglas. 1998. Financial Illiteracy, Education, and Retirement Saving. In Living with Defined Contribution Pensions. Eds, O.S. Mitchell and S. Schieber. Philadelphia: University of Pennsylvania Press: 38-68.

Bernheim, Douglas, Daniel Garrett, and Dean Maki. 2001. Education and Saving: The Longterm Effects of High School Financial Curriculum Mandates, Journal of Public Economics 80: 435-565.

Bernheim, Douglas, and Daniel Garrett. 2003. The Effects of Financial Education in the Workplace: Evidence from a Survey of Households, Journal of Public Economics 87: 1487-1519.

Bernheim, Douglas, and John Karl Scholz. 1993. Private Saving and Public Policy, in Tax Policy and the Economy, James Poterba (ed.), MIT Press 7: 73-110.

Bertrand, Marianne and Adair Morse. 2011. Information Disclosure, Cognitive Biases, and Payday Borrowing. Journal of Finance 66(6): 1865-1893.

Beshears, John, James Choi, David Laibson, and Brigitte Madrian. 2012. Default Stickiness among Low-Income Individuals. RAND Working Paper.

Blanton, Kimberly. 2012. The Rise of Financial Fraud. Center for Retirement Research brief. Boston, Mass: Boston College.

Brown, Jeffrey R., Arie Kapteyn, \& Olivia S. Mitchell. (2013). "Framing and Claiming: How Information-Framing Affects Expected Social Security Claiming Behavior." Journal of Risk and Insurance. Forthcoming. 
Brown, Jeffrey, Arie Kapteyn, Erzo Luttmer, and Olivia S. Mitchell. 2011. Do Consumers Know How to Value Annuities? Complexity as a Barrier to Annuitization. RAND Working Paper WR-924-SSA, September.

Brown, Martin and Roman Graf. 2012. Financial Literacy, Household Investment and Household Debt: Evidence from Switzerland. Swiss Institute of Banking and Finance Working Paper, University of S. Gallen, October.

Browning, Martin, and Annamaria Lusardi. 1996. Household Saving: Micro Theories and Micro Facts. Journal of Economic Literature 34: 1797-1855.

Bruhn, Miriam, Arianna Legovini, and Bilal Zia. 2012. Financial Literacy for High School Students and Their Parents: Evidence from Brazil. World Bank Working Paper.

Bucher-Koenen, Tabea and Annamaria Lusardi. 2011. Financial Literacy and Retirement Planning in Germany. Journal of Pension Economics and Finance 10(4): 565-584.

Bucher-Koenen, Tabea and Michael Ziegelmeyer. 2011. Who Lost the Most? Financial Literacy, Cognitive Abilities and the Financial Crisis. MEA Working Paper N. 234.

Bucher-Koenen, Tabea, Annamaria Lusardi, Rob Alessie, and Martin van Rooij. 2012. How Financially Literate are Women? Some New Perspectives on the Gender Gap. Netspar Working Paper N. 31.

Bumcrot, Chris, Judy Lin, and Annamaria Lusardi. 2011. The Geography of Financial Literacy. Rand Working Paper N. WR-893-SS, November.

Bursztyn, Leonardo, Florian Ederer, Bruno Ferman, Noam Yuchtman. 2013. Understanding Peer Influence in Financial Decisions: Evidence from a Field Experiment. Working Paper, The George Washington School of Business.

Cagetti, Marco. 2003. Wealth Accumulation over the Life Cycle and Precautionary Savings. Journal of Business and Economic Statistics 21(3): 339-353.

Calvet, Laurent, John Campbell, and Paolo Sodini. 2007. Down or Out: Assessing the Welfare Costs of Household Investment Mistakes, Journal of Political Economy 115: 707-747.

Calvet, Laurent, John Campbell, and Paolo Sodini. 2009. Measuring the Financial Sophistication of Households. American Economic Review 99: 393-398.

Campbell, John. 2006. Household Finance. Journal of Finance 61: 1553-1604.

Carpena, Fenella, Shawn Cole, Jeremy Shapiro, Bilal Zia. 2011. Unpacking the Causal Chain of Financial Literacy. World Bank Policy Research Working Paper 5798.

Center for Responsible Lending. 2004. Quantifying the Economic Cost of Predatory Pay-day Lending. Center Report. Durham: NC.

Chai, Jingjing, Wolfram Horneff, Raimond Maurer, and Olivia S. Mitchell. 2012. Optimal Portfolio Choice over the Life Cycle with Flexible Work, Endogenous Retirement, and Lifetime Payouts. Review of Finance 15(4): 875-907.

Chan, Sewin, and Anne Stevens. 2008. What You Don't Know Cannot Help You: Pension Knowledge and Retirement Decision-making. Review of Economics and Statistics 90: 253-266.

Chen, Haiyang and Ronald P. Volpe. 1998. An Analysis of Personal Financial Literacy among College Students. Financial Services Review 7: 107-128.

Chen, Haiyang, and Ronald P. Volpe. 2002. Gender Differences in Personal Financial Literacy among College Students. Financial Services Review, 11(3): 289.

Christelis, Dimitris, Tullio Jappelli, and Mario Padula. 2010. Cognitive Abilities and Portfolio Choice, European Economic Review 54: 18-39. 
Christiansen, Charlotte, Juanna Joensen, and Jesper Rangvid. 2008. Are Economists More Likely to Hold Stocks? Review of Finance 12: 465-496.

Chiteji, Ngina, and Frank Stafford. 1999. Portfolio Choices of Parents and their Children as Young Adults: Asset Accumulation by African American Families. American Economic Review 89: 377-380.

Choi, James, David Laibson, and Brigitte C. Madrian. 2004. Plan Design and 401(k) Savings Outcomes. National Tax Journal 57: 275-298.

Choi, James, David Laibson, Brigitte C. Madrian, and Andrew Metrick. 2006. Saving for Retirement on the Path of Least Resistance. In: Behavioral Public Finance: Toward a New Agenda. Eds. Edward J. McCaffrey and Joel Slemrod. New York: Russell Sage Foundation: 304-351.

Clark, Robert, and Madeleine D’Ambrosio. 2008. Adjusting Retirement Goals and Saving Behavior: The Role of Financial Education. In Overcoming the Saving Slump: How to Increase the Effectiveness of Financial Education and Saving Programs. Ed. A. Lusardi. Chicago: University of Chicago Press: 237-256.

Clark, Robert, Melinda Morrill, and Steven Allen. 2012. Effectiveness of Employer-Provided Financial Information: Hiring to Retiring. American Economic Review. May: 314-318.

Clark, Robert, Melinda Morrill, and Steven Allen. 2012. The Role of Financial Literacy in Determining Retirement Plans. Economic Inquiry 50(4): 851-866.

Clark, Robert, Naohiro Ogawa, and Rikiya Matsukura. 2010. Low Fertility, Human Capital, and Economic Growth: The Importance of Financial Education and Job Retraining. Population Dynamics and Economic Development Working Paper.

Cocco, Joao, Francisco Gomes, and Pascal Maenhout. 2005. Consumption and Portfolio Choice over the Life-cycle, Review of Financial Studies 18: 490-533.

Cole, Shawn, Xavier Giné, Jeremy Tobacman, Petia Topalova, Robert Townsend, and James Vickery. 2013. Barriers to Household Risk Management: Evidence from India. American Economic Journal: Applied Economics 5(1): 104-135.

Cole, Shawn, Thomas Sampson, and Bilal Zia. 2011. Prices or Knowledge? What Drives Demand for Financial Services in Emerging Markets? Journal of Finance 66(6):19331967.

Collins, J. Michael. 2011. Improving Financial Literacy: The Role of Nonprofit Providers. In Financial Literacy: Implications for Retirement Security and the Financial Marketplace. Eds. O. S. Mitchell and A. Lusardi. Oxford: Oxford University Press: 268-187.

Collins, J. Michael and Colin M. O'Rourke. 2010. Financial Education and Counseling: Still Holding Promise. Journal of Consumer Affairs 44(3): 483-489.

Crossan, Diana. 2011. How to Improve Financial Literacy: Some Successful Strategies. In Financial Literacy: Implications for Retirement Security and the Financial Marketplace. Eds. O. S. Mitchell and A. Lusardi. Oxford: Oxford University Press: 241-254.

Deevy, Martha, Shoshana Lucich, and Michaela Beals. 2012. Scams, Schemes, and Swindles: A Review of Consumer Financial Fraud Research. Stanford Financial Fraud Research Center Working Paper.

Delavande, Adeline, Susann Rohwedder, and Robert Willis. 2008. Preparation for Retirement, Financial Knowledge and Cognitive Resources. MRRC Working Paper Series 190.

De Mel, Suresh, David McKenzie, and Christopher Woodruff. 2008. Getting Credit to High Return Microentrepreneurs: The Result of an Information Intervention. World Bank Economic Review 456-486. 
DeNardi, Mariacristina, Eric French and John Bailey Jones. 2011. Why Do the Elderly Save? The Role of Medical Expenses. Journal of Political Economy 118(1): 39-75.

Disney, Richard and John Gathergood. 2012. "Financial Literacy and Consumer Credit Portfolios." Working Paper, University of Nottingham.

Drexel, Alejandro, Greg Fischer and Antoinette Schoar, 2011. Keeping it Simple: Financial Literacy and Rules of Thumb, Working Paper, MIT.

Duflo, Esther, and Emmanuel Saez. 2003. The Role of Information and Social Interactions in Retirement Plan Decisions: Evidence from a Randomized Experiment. Quarterly Journal of Economics 118: 815-842.

Duflo, Esther, and Emmanuel Saez. 2004. Implications of Pension Plan Features, Information, and Social Interactions for Retirement Saving Decisions. In Pension Design and Structure: New Lessons from Behavioral Finance. Eds. O. Mitchell and S. Utkus. Oxford: Oxford University Press: 137-153.

Elliehausen, Gregory, Christopher Lundquist, and Michael Staten. 2007. The Impact of Credit Counseling on Subsequent Borrower Behavior. Journal of Consumer Affairs 41(1): 1-28.

Employee Benefit Retirement Institute. 2007. Retirement Confidence Survey. http://www.ebri.org/surveys/rcs/

FDIC Unbanked/Underbanked Survey Study Group. 2009. FDIC National Survey of Unbanked and Underbanked Households. Washington, DC: Federal Deposit Insurance Corporation.

Federal Trade Commission. 2012. Consumer Sentinel Network Data Book. Washington D.C: FTC.

Financial Industry National Regulatory Authority (FINRA). 2006. Investor Literacy and Fraud Susceptibility Survey: Executive Summary. Washington, DC: FINRA. http://www.finra.org/Investors/ProtectYourself/AvoidInvestmentFraud/

FINRA Investor Education Foundation. 2009. Financial Capability in the United States. National Survey - Executive Summary, December 2009.

Finke, Michael. 2013. Financial Advice: Does It Make a Difference? In: The Market for Retirement Financial Advice. Eds. O. S. Mitchell and K. Smetters. Oxford, UK: Oxford University Press. Forthcoming.

Finke, Michael, John Howe, and Sandra Houston. 2011. Old Age and the Decline in Financial Literacy. SSRN http://ssrn.com/abstract $=1948627$

Fonseca, Raquel, Kathleen J. Mullen, Gema Zamarro, and Julie Zissimopoulos. 2012. What explains the gender gap in financial literacy? The Role of Household Decision Making. Journal of Consumer Affairs Spring: 90-106.

Fornero, Elsa and Chiara Monticone. 2011. Financial Literacy and Pension Plan Participation in Italy. Journal of Pension Economics and Finance 10(4): 547-564

Fox, Jonathan, Suzanne Bartholomae, and Jinkook Lee. 2005. Building the Case for Financial Education. Journal of Consumer Research. 39(1): 195-214

French, Eric. 2005. The Effects of Health, Wealth, and Wages on Labor Supply and Retirement Behavior. Review of Economic Studies 72(2): 395-427.

French, Kenneth. 2008. The Cost of Active Investing. Journal of Finance 63: 1537-1573.

Friedman, Milton. 1957. A Theory of the Consumption Function. Princeton: Princeton University Press.

Gale, William, Benjamin Harris and Ruth Levine. 2012. Raising Household Saving. Does Financial Education Work? Social Security Bulletin, N. 72-2, May 2012. 
Gerardi, Kristopher, Lorenz Goette, and Stephan Meier. 2010. Financial Literacy and Subprime Mortgage Delinquency: Evidence from a Survey Matched to Administrative Data. Federal Reserve Bank of Atlanta Working Paper 2010-10.

Glewwe, Paul. 2002. Schools and Skills in Developing Countries: Education Policies and Socioeconomic Outcomes. Journal of Economic Literature 40: 436-482.

Goda, Shah Gopi, Colleen Manchester, and Aaron Sojourner. 2012. What Will my Account Really be Worth? An Experiment on Exponential Growth Bias and Retirement Saving. RAND Working Paper WR-873.

Gourinchas, Pierre-Olivier and Jonathan Parker. 2002. Consumption over the Life Cycle. Econometrica 70 (1): 47-89.

Grinblatt, Mark, Matt Keloharju, and Juhani Linnainmaa. 2011. IQ and Stock Market Participation. Journal of Finance 66(6): 2121-2164.

Gustman, Alan, Thomas Steinmeier, and Nahid Tabatabai. 2008. Do Workers Know About Their Pensions? Comparing Workers and Employers' Pension Information. In Overcoming the Saving Slump: How to Increase the Effectiveness of Financial Education and Saving Programs, Ed. A. Lusardi. Chicago: University of Chicago Press: 47-81.

Gustman, Alan, Thomas Steinmeier, and Nahid Tabatabai. 2010. Financial Knowledge and Financial Literacy at the Household Level. NBER Working Paper 16500.

Haliassos, Michael, and Carol Bertaut. 1995. Why Do So Few Hold Stocks? Economic Journal 105: 1110-1129.

Hanushek, Eric and Ludger Woessmann. 2008. The Role of Cognitive Skills in Economic Development. Journal of Economic Literature 46(3): 607-668.

Hastings, Justine, Brigitte Madrian and William Skimmyhorn. 2012. Financial Literacy, Financial Education and Economic Outcomes. NBER Working Paper 18412.

Hastings, Justine, and Olivia S. Mitchell. 2011. How Financial Literacy and Impatience Shape Retirement Wealth and Investment Behaviors. NBER Working Paper 16740.

Hastings, Justine, Olivia S. Mitchell, and Eric Chyn. 2011. Fees, Framing, and Financial Literacy in the Choice of Pension Managers. In Financial Literacy: Implications for Retirement Security and the Financial Marketplace. Eds. O. S. Mitchell and A. Lusardi. Oxford: Oxford University Press: 101-115.

Hastings, Justine, and Lydia Tejeda-Ashton. 2008. Financial Literacy, Information, and Demand Elasticity: Survey and Experimental Evidence from Mexico. NBER Working Paper 14538.

Hathaway, Ian and Sameer Khatiwada. 2008. Do Financial Education Programs Work? Federal Reserve Bank of Cleveland Working Paper.

Heinberg, Aileen, Angela Hung, Arie Kapteyn, Annamaria Lusardi, and Joanne Yoong. 2010. Five Steps to Planning Success. RAND Working Paper No. WR-790-SSA, 2010.

Hilgert, Marianne, Jeanne Hogarth, and Sondra Beverly. 2003. Household Financial Management: The Connection between Knowledge and Behavior. Federal Reserve Bulletin, 309-322.

Hira, Tahira. 2010. The NEFE Quarter Century Project: Implications for Researchers, Educators and Policy Makers from a Quarter Century of Financial Education. National Endowment for Financial Education Working Paper.

http://www.nefe.org/Portals/0/WhatWeProvide/PrimaryResearch/PDF/TheQtrCenturyProjec t_FinalSeminal.pdf 
Hira, Tahira, Sabri, Mohamed, and Cäzilia Loibl. 2013. Financial Socialization's Impact on Investment Orientation and Household Net Worth. International Journal of Consumer Studies 37(1): 29-35.

Hirad, Abdighani, and Peter Zorn. 2002. A Little Knowledge is a Good Thing: Empirical Evidence of the Effectiveness of Pre-Purchase Homeownership Counseling. In Low-income Homeownership: Examining the Unexamined Goal. Eds. Nicolas Retsinas, Eric Belsky, 146-174. Cambridge, Mass.\& Washington, D.C.: Joint Center for Housing Studies; Brookings Institution Press.

Holzmann, Robert. 2011. Bringing Financial Literacy and Education to Low and Middle Income Countries. In Financial Literacy: Implications for Retirement Security and the Financial Marketplace. Eds. O. S. Mitchell and A. Lusardi. Oxford: Oxford University Press: 255267.

Huston, Sandra. 2010. Measuring Financial Literacy. Journal of Consumer Affairs, 44: 296-316.

Hsu, Joanne. 2011. Aging and Strategic Learning: The Impact of Spousal Incentives on Financial Literacy. Networks Financial Institute Working Paper 2011-WP-06, Indiana State University.

Hung, Angela, Andrew Parker and Joanne Yoong. 2009. Defining and Measuring Financial Literacy, RAND Working Paper 708.

Hung Angela, Joanne Yoong, and Elizabeth Brown 2012. Empowering Women Through Financial Awareness and Education. OECD Working Papers on Finance, Insurance and Private Pensions, No. 14.

Hurst, Eric and Mark Aguiar. 2005. Consumption vs Expenditure. Journal of Political Economy. 113(5): 919-948.

Hurst, Eric and Mark Aguiar. 2007. Measuring Trends in Leisure: The Allocation of Time Over Five Decades. Quarterly Journal of Economics 122(3): 969-1006.

Jappelli, Tullio. 2010. Economic Literacy: An International Comparison. The Economic Journal. 120: 429-451.

Jappelli, Tullio, and Mario Padula. 2011. Investment in Financial Knowledge and Saving Decisions. CSEF Working Paper 272, University of Salerno.

Kast, Felipe, Stephan Meier, and Dina Pomeranz. 2012. Under-Savers Anonymous: Evidence on Self-Help Groups and Peer Pressure as a Savings Commitment Device. HBS Working Paper 12-060.

Kézdi, Gabor, and Robert Willis. 2011. Household Stock Market Beliefs and Learning. NBER WP 17614.

Kimball, Miles, and Tyler Shumway. 2006. Investor Sophistication and the Participation, Home Bias, Diversification, and Employer Stock Puzzles. University of Michigan Working Paper.

Klapper, Leora and Georgios Panos. 2011. Financial Literacy and Retirement Planning: The Russian Case. Journal of Pension Economics and Finance 10(4): 599-618.

Klapper, Leora, Annamaria Lusardi, and Georgios Panos. 2012. Financial Literacy and the Financial Crisis. NBER Working Paper 17930.

Korniotis, George and Alok Kumar. 2011. Do Older Investors Make Better Investment Decisions? Review of Economics and Statistics 93 (4): 244-265.

Laibson, David. 2011. The Age of Reason. Presentation for the Department of Economics, Harvard University. http://www.economics.harvard.edu/faculty/laibson/files/Age\%2Bof\%2BReason.pdf 
Li, Geng. 2009. Information Sharing and Stock Market Participation: Evidence from Extended Families. Federal Reserve Board Working Paper.

Lu, Timothy, Olivia S Mitchell, and Stephen P. Utkus. 2010. An Empirical Analysis of 401(k) Loan Defaults. MRRC Working Paper WR-799-SSA.

Lusardi, Annamaria. 2011. Americans' Financial Capability. NBER Working Paper 17103.

Lusardi, Annamaria, and Carlo de Bassa Scheresberg. 2012. Financial Literacy and High-Cost Borrowing in the United States. Working Paper presented at the 2012 APPAM Fall Research Conference.

Lusardi, Annamaria, Punam Keller, and Adam Keller. 2008. New Ways to Make People Save: A Social Marketing Approach, In Overcoming the Saving Slump: How to Increase the Effectiveness of Financial Education and Saving Programs. Ed. A. Lusardi. Chicago: University of Chicago Press: 209-236.

Lusardi, Annamaria, Pierre-Carl Michaud, and Olivia S. Mitchell. 2011. Optimal Financial Literacy and Saving for Retirement. Wharton School Pension Research Council Working Paper WP2011-20.

Lusardi, Annamaria, Pierre-Carl Michaud, and Olivia S. Mitchell. 2013. Optimal Financial Literacy and Wealth Inequality. NBER Working Paper 18669.

Lusardi, Annamaria, and Olivia S. Mitchell. 2007a. Baby Boomers' Retirement Security: The Role of Planning, Financial Literacy and Housing Wealth. Journal of Monetary Economics 54: 205-224.

Lusardi, Annamaria, and Olivia S. Mitchell. 2007b. Financial Literacy and Retirement Preparedness: Evidence and Implications for Financial Education. Business Economics, 35-44.

Lusardi, Annamaria, and Olivia S. Mitchell. 2008. Planning and Financial Literacy: How Do Women Fare? American Economic Review 98: 413-417.

Lusardi, Annamaria, and Olivia S. Mitchell. 2009. How Ordinary Consumers Make Complex Economic Decisions: Financial Literacy and Retirement Readiness. NBER Working Paper 15350.

Lusardi, Annamaria, and Olivia S. Mitchell. 2011a. The Outlook for Financial Literacy. In Financial Literacy: Implications for Retirement Security and the Financial Marketplace. Eds. O. S. Mitchell and A. Lusardi. Oxford, Oxford University Press: 1-15.

Lusardi, Annamaria, and Olivia S. Mitchell. 2011b. Financial Literacy and Planning: Implications for Retirement Wellbeing. In Financial Literacy: Implications for Retirement Security and the Financial Marketplace. Eds. O. S. Mitchell and A. Lusardi. Oxford, Oxford University Press: 17-39.

Lusardi, Annamaria and Olivia S. Mitchell. 2011c. Financial Literacy around the World: An Overview. Journal of Pension Economics and Finance 10(4): 497-508.

Lusardi, Annamaria and Olivia S. Mitchell. 2011d. Financial Literacy and Retirement Planning in the United States. Journal of Pension Economics and Finance 10(4): 509-525.

Lusardi, Annamaria, Olivia S. Mitchell, and Vilsa Curto. 2012. Financial Sophistication in the Older Population. NBER Working Paper, no. 17863

Lusardi, Annamaria, Olivia S. Mitchell, and Vilsa Curto. 2010. Financial Literacy Among the Young. Journal of Consumer Affairs 44 (2): 358-380.

Lusardi, Annamaria, and Peter Tufano. 2009a. Debt Literacy, Financial Experiences, and Overindebtedness. NBER Working Paper 14808. 
Lusardi, Annamaria, and Peter Tufano. 2009b. Teach Workers about the Peril of Debt, Harvard Business Review. November: 22-24.

Lusardi, Annamaria, Daniel J. Schneider, and Peter Tufano. 2011. "Financially Fragile Households: Evidence and Implications." Brookings Papers on Economic Activity Spring: 83-134.

Lyons, Angela, Lance Palmer, Korallalage Jayaratne, and Eric Scherpf. 2006. Are We Making the Grade? A National Overview of Financial Education and Program Evaluation. Journal of Consumer Affairs 40 (2): 208-235.

Lyons, Angela and Urvi Neelakantan. 2008. Potential and Pitfalls of Applying Theory to the Practice of Financial Education. Journal of Consumer Affairs. 42(1): 106-112.

Mahdavi, Mahnaz. 2012. Financial Literacy among Educated Women: Room for Improvement. Working Paper, Smith College.

Mandell, Lewis. 2008. Financial Education in High School. In Overcoming the Saving Slump: How to Increase the Effectiveness of Financial Education and Saving Programs., Ed. A. Lusardi. Chicago: University of Chicago Press: 257-279.

Mandell, Lewis. 2004. Financial Literacy: Are We Improving? Washington, D.C.: Jump\$tart Coalition for Personal Financial Literacy.

Mandell, Lewis. 1997. Our Vulnerable Youth: The Financial Literacy of American $12^{\text {th }}$ Graders. Jump\$tart Coalition for Personal Financial Literacy.

Madrian, Brigitte and Dennis Shea. 2001. The Power of Suggestion: Inertia in 401(k) Participation and Saving Behavior. Quarterly Journal of Economics. 116 (4): 1149-1187.

Markow, Dana, and Kelly Bagnaschi. 2005. What American Teens \& Adults Know About Economics. National Council on Economic Education Report.

Martin, Matthew, 2007. "A Literature Review on the Effectiveness of Financial Education." Federal Reserve Bank of Richmond, Working Paper 07-03.

McArdle, James, James Smith, and Robert Willis. 2009. Cognition and Economic Outcomes in the Health and Retirement Survey NBER Working Paper No. 15266.

Meier, Steven, and Charles Sprenger. 2008. Discounting Financial Literacy: Time Preferences and Participation in Financial Education Programs. Columbia Business School Working Paper.

Mitchell, Olivia S., John Piggott, and Noriyuki Takayama (eds). 2011.Securing Lifelong Retirement Income: Market Developments and Policy Issues. Oxford: Oxford University Press.

Mitchell, Olivia S. and Kent Smetters (eds). 2013. The Market for Retirement Financial Advice. Oxford: Oxford University Press. Forthcoming.

Mitchell, Olivia S. and Stephen Utkus. 2012. Target-Date Funds in 401(k) Retirement Plans NBER Working Paper No. 17911.

Modigliani, Franco, and Richard Brumberg. 1954. Utility Analysis and the Consumption Function: An Interpretation of Cross-section Data. In Post-Keynesian Economics. Ed. K. Kurihara. New Brunswick, NJ: Rutgers University Press: 388-436.

Moore, Danna. 2003. Survey of Financial Literacy in Washington State: Knowledge, Behavior, Attitudes and Experiences. Washington State University Social and Economic Sciences Research Center Technical Report 03-39.

Mottola, Gary. 2012. In Our Best Interest: Women, Financial Literacy and Credit Card Behavior. Insights, FINRA Investor Education Foundation. 
Organization for Economic Co-Operation and Development (OECD). 2005. Improving Financial Literacy: Analysis of Issues and Policies. Paris, France: OECD.

Poterba, James, Steven Venti, and David Wise. 2008. The Changing Landscape of Pensions in the United States. In Overcoming the Saving Slump: How to Increase the Effectiveness of Financial Education and Saving Programs. Ed. A. Lusardi. Chicago: University of Chicago Press: 17-46.

Poterba, James, Steven Venti, and David Wise. 2013. Health, Education, and the PostRetirement Evolution of Household Assets. NBER Working Paper No. 18695.

President's Advisory Committee on Financial Literacy (PACFL). 2008. Annual Report to the President: Executive Summary.

Romagnoli, Angela and Maurizio Trifilidis. 2012. Does Financial Education in School Work? Evidence from Italy. Bank of Italy Working Paper.

Scholz, John Karl, Ananth Seshadri, and Surachai Khitatrakun. 2006. Are Americans Saving "Optimally" For Retirement? Journal of Political Economy 114: 607-643.

Sekita, Shizuka. 2011. Financial Literacy and Retirement Planning in Japan. Journal of Pension Economics and Finance 10(4): 637-656.

Shim, Soyeon, Jing Xiao, Bonnie Barber and Angela Lyons. 2009. Pathway to Life Success: A Conceptual Model of Financial Well-being for Young Adults, Journal of Applied Development Psychology 30: 708-723.

Shim, Soyeon., Bonnie Barber,., Noel Card, Jing Xiao Joyce Serido2010. Financial Socialization of First-year College Students: The Role of Parents, Work, and Education. Journal of Youth \& Adolescence 39(12): 1457-1470.

Skinner, Jonathan. 2007. Are You Sure You're Saving Enough for Retirement? Journal of Economic Perspectives Summer: 59-80.

Song, Changcheng. 2011. Financial Illiteracy and Pension Contributions: A Field Experiment on Compound Interest in China. University of California, Berkeley Working Paper.

Stango, Victor, and Jonathan Zinman. 2009. Exponential Growth Bias and Household Finance. Journal of Finance 64: 2807-2849.

Tennyson, Sharon and Chau Nguyen. 2001. State Curriculum Mandates and Student Knowledge of Personal Finance. Journal of Consumer Affairs 35 (2): 241-262.

Thaler, Richard and Shlomo Benartzi. 2004. Save More Tomorrow: Using Behavioral Economics to Increase Employee Saving. Journal of Political Economy,112(1, part 2): S164-S196.

Thaler, Richard and Cass Sunstein. 2010. Nudge: Improving Decisions About Health, Wealth, and Happiness. New Haven: Yale University Press.

Thaler, Richard, Cass Sunstein, and John Balz. 2010. Choice Architecture. SSRN Working Paper. http://ssrn.com/abstract=1583509 or http://dx.doi.org/10.2139/ssrn.1583509

U.S. Securities and Exchange Commission (SEC). 2012. Study Regarding Financial Literacy Among Investors As Required by Section 917 of the Dodd-Frank Wall Street Reform and Consumer Protection Act. SEC Staff Study, August.

Utkus, Stephen, and Jean Young. 2011. Financial Literacy and 401(k) Loans. In Financial Literacy: Implications for Retirement Security and the Financial Marketplace. Eds. O. S. Mitchell and A. Lusardi. Oxford: Oxford University Press: 59-75.

Van Rooij, Maarten, Annamaria Lusardi, and Rob Alessie. 2011. Financial Literacy and Stock Market Participation. Journal of Financial Economics 101(2): 449-472. 
Van Rooij, Maarten, Annamaria Lusardi, and Rob Alessie. 2012. Financial Literacy, Retirement Planning, and Households Wealth. Economic Journal 122: 449-478.

Venti, Steven, and David Wise. 1998. The Cause of Wealth Dispersion at Retirement: Choice or Chance? American Economic Review 88: 185-191.

Venti, Steven, and David Wise. 2001. Choice, Chance, and Wealth Dispersion. In Aging Issues in the United States and Japan. Eds. S. Ogura, T. Tachibanaki, and D. Wise. Chicago: University of Chicago Press: 25-64.

Walstad, William, Ken Rebeck and Richard MacDonald. 2010. The Effects of Financial Education on the Financial Knowledge of High School Students. Journal of Consumer Affairs 44(2): 336-357.

Way, Wendy and Karen Holden. 2009. Teachers' Background and Capacity to Teach Personal Finance: Results of a National Study. Journal of Financial Counseling and Planning 20(2): 64-78.

Willis, Lauren. 2008. Against Financial Literacy Education. Public Law and Legal Theory Research Paper Series Research Paper No. \#08-10. University of Pennsylvania.

Yoong, Joanne. 2011. Financial Illiteracy and Stock Market Participation: Evidence from the RAND American Life Panel. In Financial Literacy: Implications for Retirement Security and the Financial Marketplace. Eds O. S. Mitchell and A. Lusardi. Oxford: Oxford University Press: 76-97. 
Table 1. Financial Literacy Patterns

Source: Authors' computations from HRS 2004 Planning Module

Panel A: Distribution of Responses to Financial Literacy Questions

\begin{tabular}{|l|cccc|}
\hline \multirow{2}{*}{} & \multicolumn{4}{|c|}{ Responses } \\
\cline { 2 - 5 } & Correct & Incorrect & DK & Refuse \\
\hline \multirow{2}{*}{ Compound Interest } & $67.1 \%$ & $22.2 \%$ & $9.4 \%$ & $1.3 \%$ \\
& & & & \\
Inflation & $75.2 \%$ & $13.4 \%$ & $9.9 \%$ & $1.5 \%$ \\
& & & $33.7 \%$ & $0.9 \%$ \\
\hline
\end{tabular}

Panel B: Joint Probabilities of Being Correct to Financial Literacy Questions

\begin{tabular}{|c|cccc|}
\hline & $\begin{array}{c}\text { All 3 responses } \\
\text { correct }\end{array}$ & $\begin{array}{c}\text { Only 2 responses } \\
\text { correct }\end{array}$ & $\begin{array}{c}\text { Only 1 response } \\
\text { correct }\end{array}$ & $\begin{array}{c}\text { No responses } \\
\text { correct }\end{array}$ \\
\hline & & & & \\
Proportion & $34.3 \%$ & $35.8 \%$ & $16.3 \%$ & $9.9 \%$ \\
\hline
\end{tabular}

Note: DK = respondent indicated “don't know.” 
Figure 1. Financial Literacy Scores Around the World: Percent Who Correctly Answer All Three Financial Literacy Questions, or No Questions Correct

Source: Adapted from Lusardi and Mitchell (2011c)

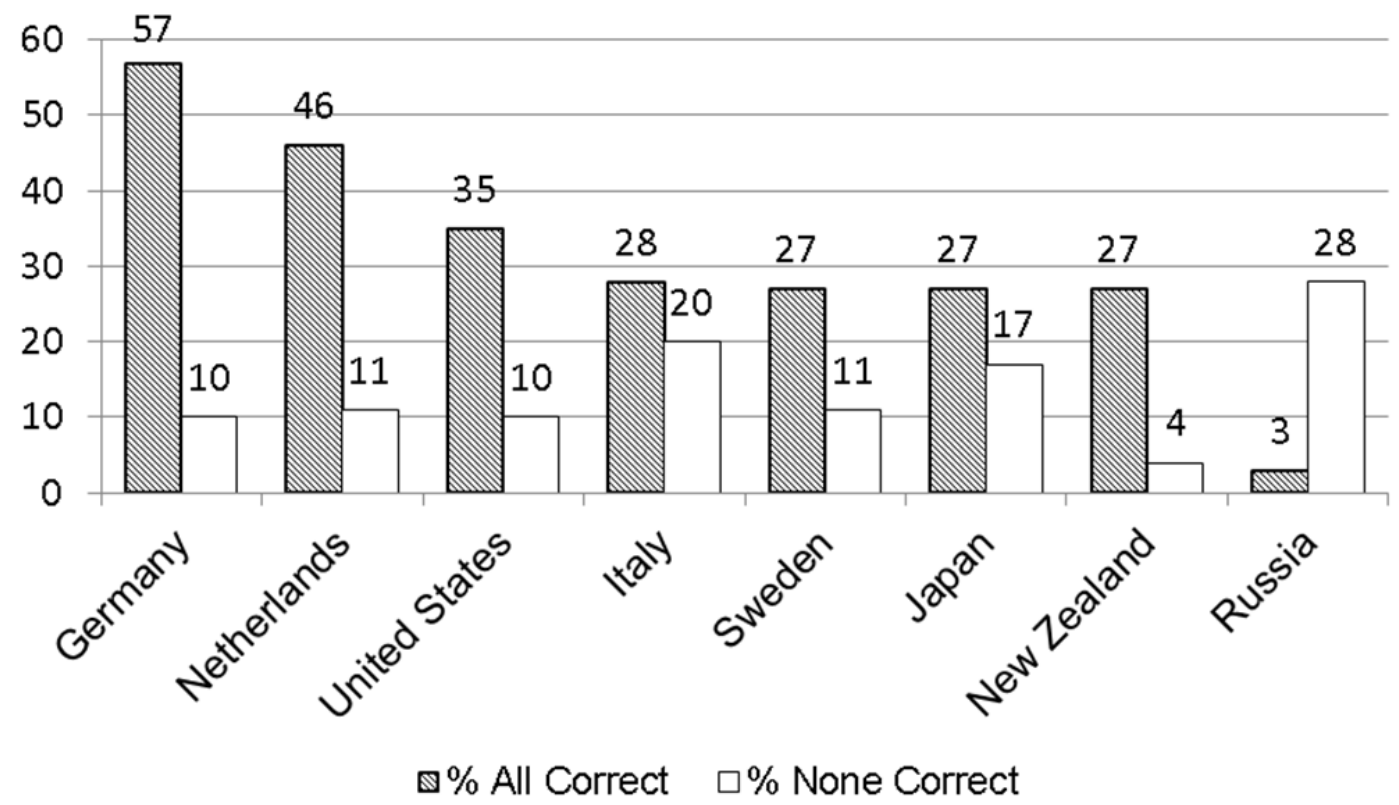

